\title{
Ecological Communities on the Red Rock Lakes \\ National Wildlife Refuge: \\ Inventory and Review of Aspen and Wetland Systems
}

Prepared for:

Red Rock Lakes National Wildlife Refuge

\section{Prepared by:}

Catherine Jean, Paul Hendricks, Marc Jones, Steve Cooper and John Carlson

Montana Natural Heritage Program

Natural Resource Information System

Montana State Library

June 2002

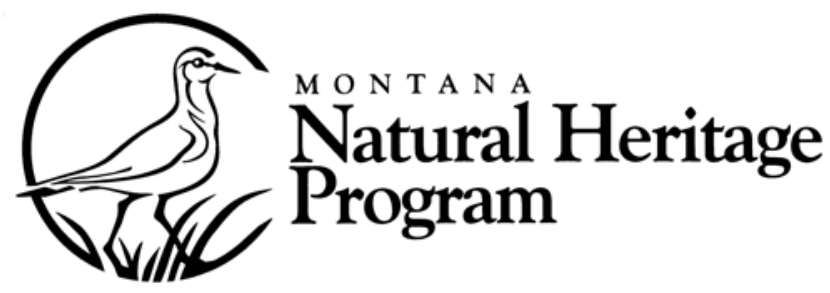




\title{
Ecological Communities on the Red Rock Lakes National Wildlife Refuge: Inventory and Review of Aspen and Wetland Systems
}

\author{
Prepared for : \\ Red Rock Lakes National Wildlife Refuge \\ U.S. Fish and Wildlife Service \\ Monida Star Route Box 15 Lima, Montana 59736 \\ Purchase Order \# \\ 601810P771 \\ Prepared by: \\ Catherine Jean, Paul Hendricks, Marc Jones, Steve Cooper and John Carlson \\ Montana Natural Heritage Program \\ 1515 East Sixth Avenue \\ Helena, Montana 59620-1800
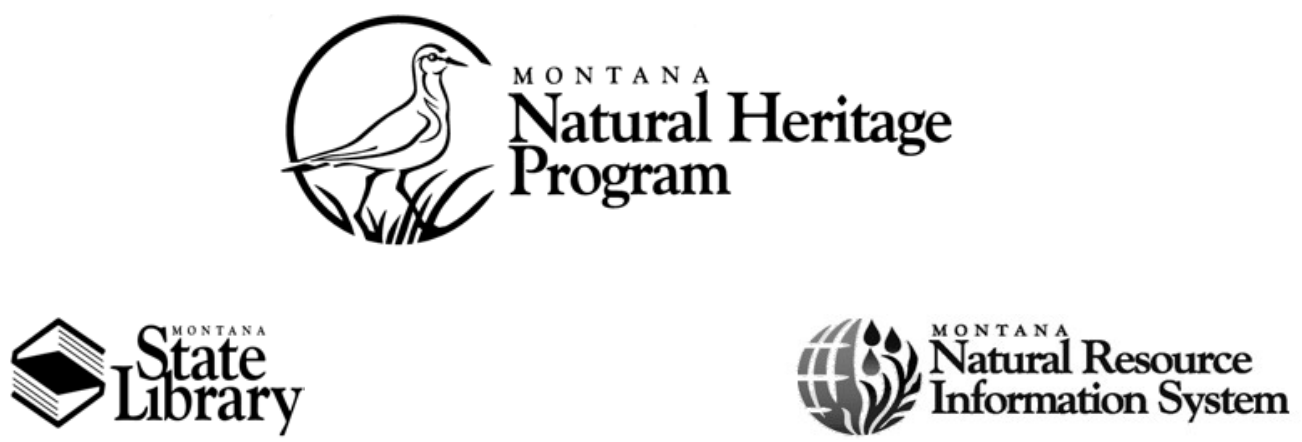

(C) 2002 Montana Natural Heritage Program

P.O. Box $201800 \bullet 1515$ East Sixth Ave • Helena, MT 59620-1800 406-444-3009

This document should be cited as follows:

C. Jean., et al. 2002. Ecological Communities on the Red Rocks Lakes National Wildlife Refuge: Inventory and Review of Aspen and Wetland Systems. Report to the Red Rock Lakes National Wildlife Refuge. Montana Natural Heritage Program, Helena, Montana. 33 pp. plus appendices. 


\section{ACKNOWLEDGMENTS}

Thanks to Danny Gomez, Refuge Manager at Red Rock Lakes National Wildlife Refuge for sponsoring this project and for providing access to internal files. We also appreciate Tim Swanson, Project Director for The Nature Conservancy (TNC) in Centennial Valley, and TNC interns Kelly Pohl and Nathan Korb their continued interest in the biodiversity of Centennial Valley.

Thanks also to staff at the Montana Natural Heritage Program. Whitney Weber designed and produced maps for the report; Terrie Kenney processed and entered information and photographic images into program databases. This report benefitted significantly from work funded by Montana Department of Environmental Quality and administered by Linda Saul, to identify and describe significant wetlands in Montana. Thanks to Sue Crispin who helped edit and Joy Lewis for proof-reading and production assistance.

Though this report has profited from the support and contributions of many people, any errors of commission or omission rest with the authors. This project was funded by the US Fish Wildlife Service Purchase order \# 60180P771. 


\section{TABLE OF CONTENTS}

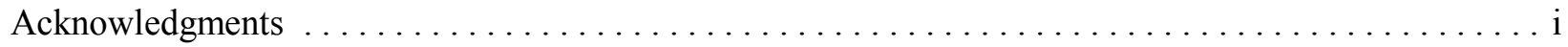

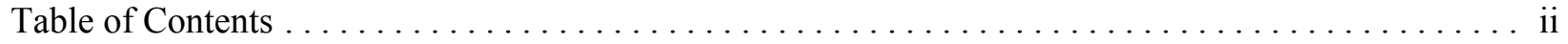

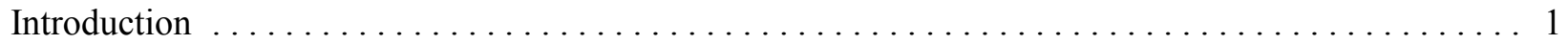

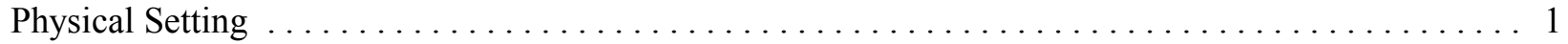

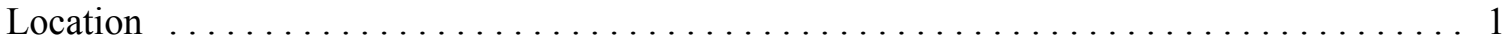

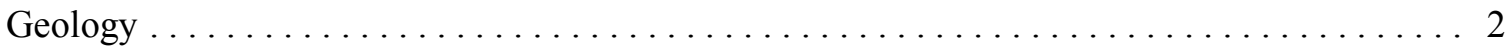

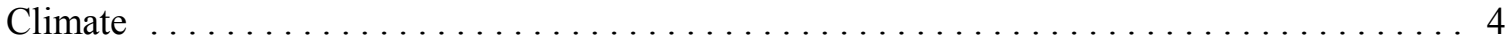

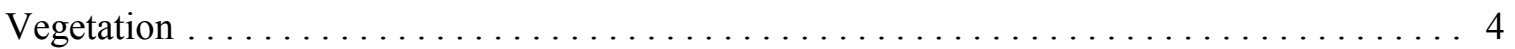

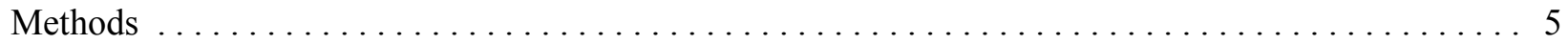

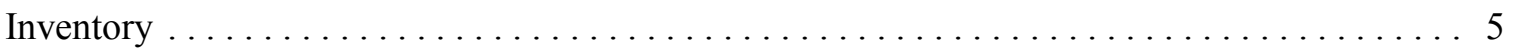

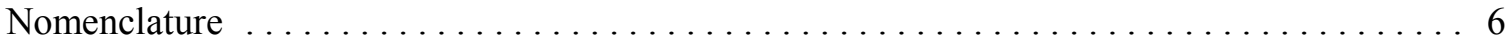

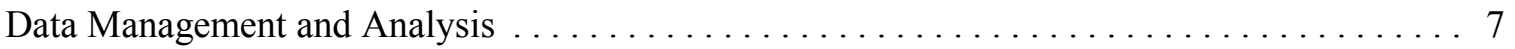

Status of Animal, Plant and Community Inventories $\ldots \ldots \ldots \ldots \ldots \ldots \ldots \ldots \ldots \ldots \ldots$

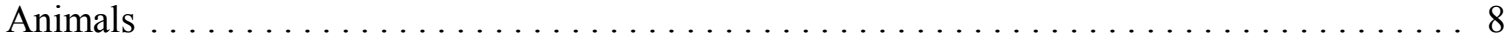

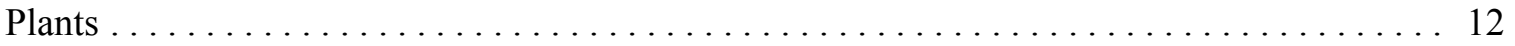

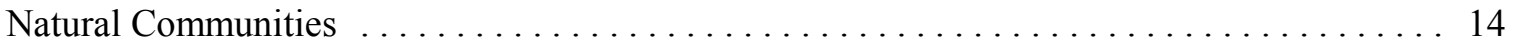

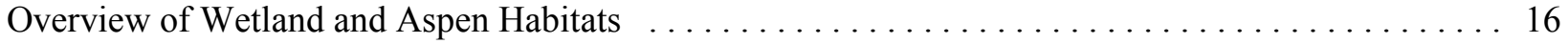

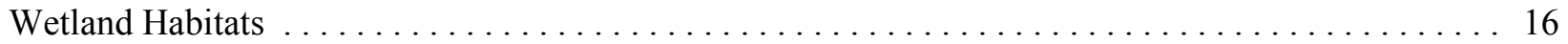

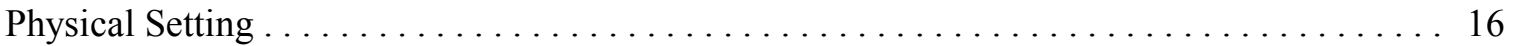

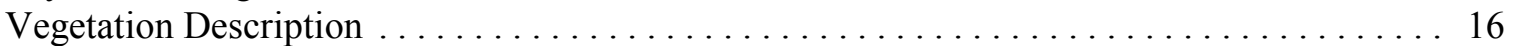

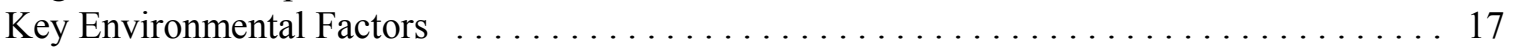

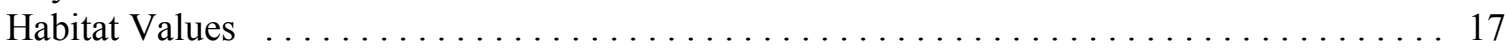

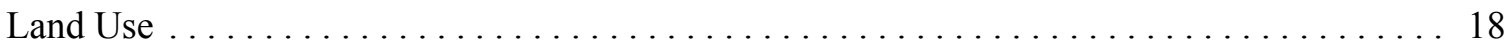

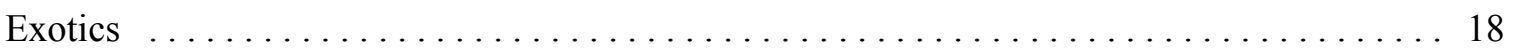

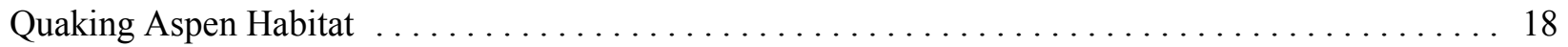

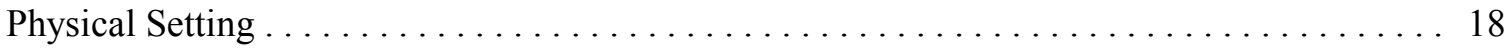

Vegetation Description ..................................... 19

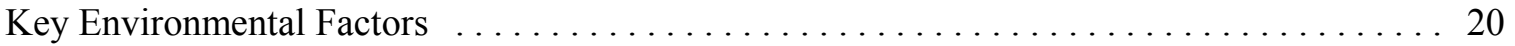

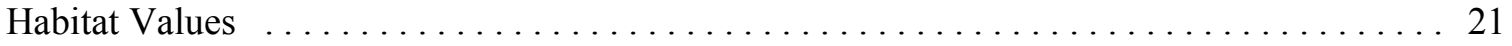

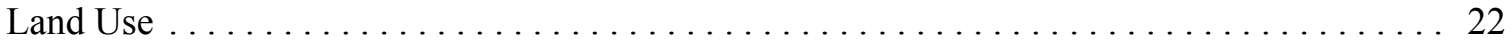

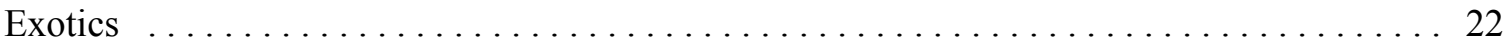

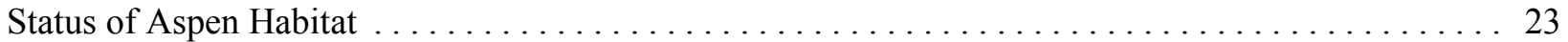

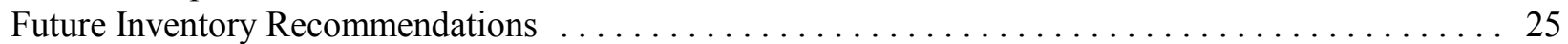

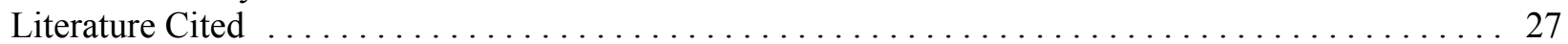

Figure 1. Red Rock Lakes National Wildlife Refuge Study Area map

Figure 2. Mapped records of breeding and non breeding amphibians

Figure 3. Mapped observation records for 16 vascular plants of concern

Figure 4. Aspen, Wetland, Sage-steppe, and Coniferous Forest Habitats on the Refuge

Table 1. Vertebrates of Concern and Conservation Interest

Table 2. Amphibians and Reptiles of Concern on Red Rocks Lakes NWR

Table 3. Vascular Plants of Concern on Red Rock Lakes NWR

Appendix A. Red Rock Lakes National Wildlife Refuge Annotated Bibliography 


\section{INTRODUCTION}

Red Rock Lakes National Wildlife Refuge (NWR) was established specifically to promote the long-term conservation of the Trumpeter Swan (Cygnus buccinator) (Banko 1960). The Refuge is part of a national network of lands and waters with the purpose to conserve, manage and where appropriate, restore fish, wildlife, and plant resources and their habitats. The NWR System Improvement Act of $1997^{1}$, requires that each Refuge prepare a comprehensive conservation plan to ensure that the biological integrity, diversity, and environmental health of the system is maintained for the benefit of present and future generation of Americans. An initial planning step, used by others (Schroeder and Askerooth 1999), is to identify and understand specific resources of concern on the Refuge.

The purpose of this report is to identify and describe the current knowledge and status, of fish, wildlife and plant populations and their related habitats on the Refuge. Our goal is to eventually describe all the principle habitats on the Refuge and identify habitat use by plant and animal species of concern. This information is intended to help Refuge staff establish habitat objectives and habitat management strategies. We also identify potentially non-compatible uses and describe potential stewardship practices that Refuge staff can utilize in their efforts to maintain or restore native biological diversity on the Refuge system.

This report provides a broad overview of the important biological resources on the Refuge and more specific descriptions of quaking aspen (Populus tremuloides) and wetland habitats. These habitats were chosen as our initial focus because of their importance on the Refuge. Wetlands and moist meadows make up 70\% of the Refuge and many resident species of concern are wetland or riparian dependent. Quaking aspen also is an important vegetation community. The distribution and pattern of quaking aspen interspersed with sagebrush steppe and coniferous forests makes these sites valuable for wildlife (DeByle 1985). Quaking aspen stands are biologically rich and often have high forb diversity. Forb and grain seeds are a food source for voles, which, in turn, are prey for owls and hawks. Quaking aspen communities with multi-age trees and standing dead provide an abundance of cavity bearing trees, which provide important nesting and roosting habitat for birds and bats (Flack 1976, Winternitz 1980, Crampton and Barclay 1998, Kalcounis and Brigham 1998). A decline in quaking aspen habitat is likely to cause changes in avian and bat diversity. The decline of quaking aspen in the Northern Rocky Region is a concern to resource managers.

\section{Physical Setting}

\section{LOCATION}

The Red Rock Lakes National Wildlife Refuge is located at the southern extreme of southwestern Montana, in Beaverhead County (Figure 1). It lies principally within the Centennial Valley but also includes areas on the north-facing slopes of the Centennial Mountains. Using the Forest Service's National Hierarchical Framework of Ecological Units (ECOMAP 1993, Nesser et al. 1997) the Refuge's bio-geographical context can be described at increasingly fine scales as: Middle Rocky Mountain Steppe-Coniferous Forest-Alpine Meadow Province (M332); Beaverhead Mountains Section (M332E); and two Subsections, Southwest Montana Intermontane Basins and Valleys (M332Ej) and Southern Beaverhead Mountains (M332Er).

Beyond the characteristics of the ecoregional subsections, there are several very important factors influencing the Refuge's environment. These include the east-west trending and relatively high Centennial Mountains, the high base elevation (approximately 6,600 ft.) at the valley's eastern extremity; the fact that the valley is

\footnotetext{
${ }^{1}$ Public Law $105-57,105^{\text {th }}$ Congress
} 
encompassed by extensive and relatively high uplands, and the presence of the largest lake/wetland complex in Montana. Perennial stream density is relatively low and all streams flow westward into the Red Rock River.

\section{GEOLOGY AND SOILS}

The Centennial Mountains, which form the southern border of the Refuge, are a block fault range of the Laramide Orogeny, and are the only east-west trending range of significant relief in Montana. They also form the Continental Divide in this region, which runs from Monida Pass at 6,790 ft. gradually increasing in elevation eastward for about 35 miles to the highest point on Mount Jefferson (10, $211 \mathrm{ft}$.). The eastern half of the range was extensively glaciated during the Pleistocene period, and a very rugged, north-facing escarpment towers 3,500 ft. over the south boundary of the Refuge. The streams and rivers of this area are moderately entrenched and constantly adjusting to the past and continuing uplift of surrounding mountain ranges.

The Centennial Valley is a classic high-elevation intermontane basin $(6,800 \mathrm{ft}$. at its upper end $)$ drained by the westward flowing Red Rock River, a tributary to the Beaverhead River and ultimately the Missouri River. Odell and Hellroaring Creeks originate on the north-flank of the Centennial Mountains and drain into Red Rock River. Upper and Lower Red Rock Lakes are shallow (average depth about $8 \mathrm{ft}$., artificially maintained) remnants of more extensive ancestral lakes that formed in the pluvial climates of the Pleistocene and early Holocene epochs. The geology and geochemistry of these and other lentic waters are profiled in Paullin (1973).

The Centennial Mountains and Valley were created in Paleocene and Eocene times and further elevated in the late Pliocene, with uplift continuing at a lesser rate to the present. The resulting erosion has been enormous, filling the 6-mile wide Centennial basin to an unknown depth with sediments mainly from Miocene volcanics (both nutrient-rich basalts and nutrient-poor rhyolites) and from Paleozoic, Mesozoic and early Tertiary sedimentary rock. Pleistocene sediments have been deposited over the valley floor in broad, gently sloping alluvial fans or in lakes that have expanded and contracted with the climatic fluctuations of the Pleistocene and Holocene.

In late Pleistocene and early Holocene times (about 12,000 years BP), water from melted glaciers inundated the Centennial Valley. When the waters receded, areas of unconsolidated alluvium were left exposed to prevailing winds, presumably from the northwest, as indicated by dune development being arcuate toward the southeast (though the dune-system generally trends southwest to northeast). The dunes are composed of fine sand, with silt-sized and finer materials having blown out to the east. Home to a unique flora and fauna, the dunes continue to shift according to local patterns of destabilization attributed to complex interactions of rodent activity, grazing pressure, fire, and prevailing winds. Also associated with the retreat of Pleistocene lakes are emergent beaches; those near the north shore of Red Rock Lakes are especially large and well developed. 
Figure 1. Red Rock Lakes National Wildlife Refuge Study Area map

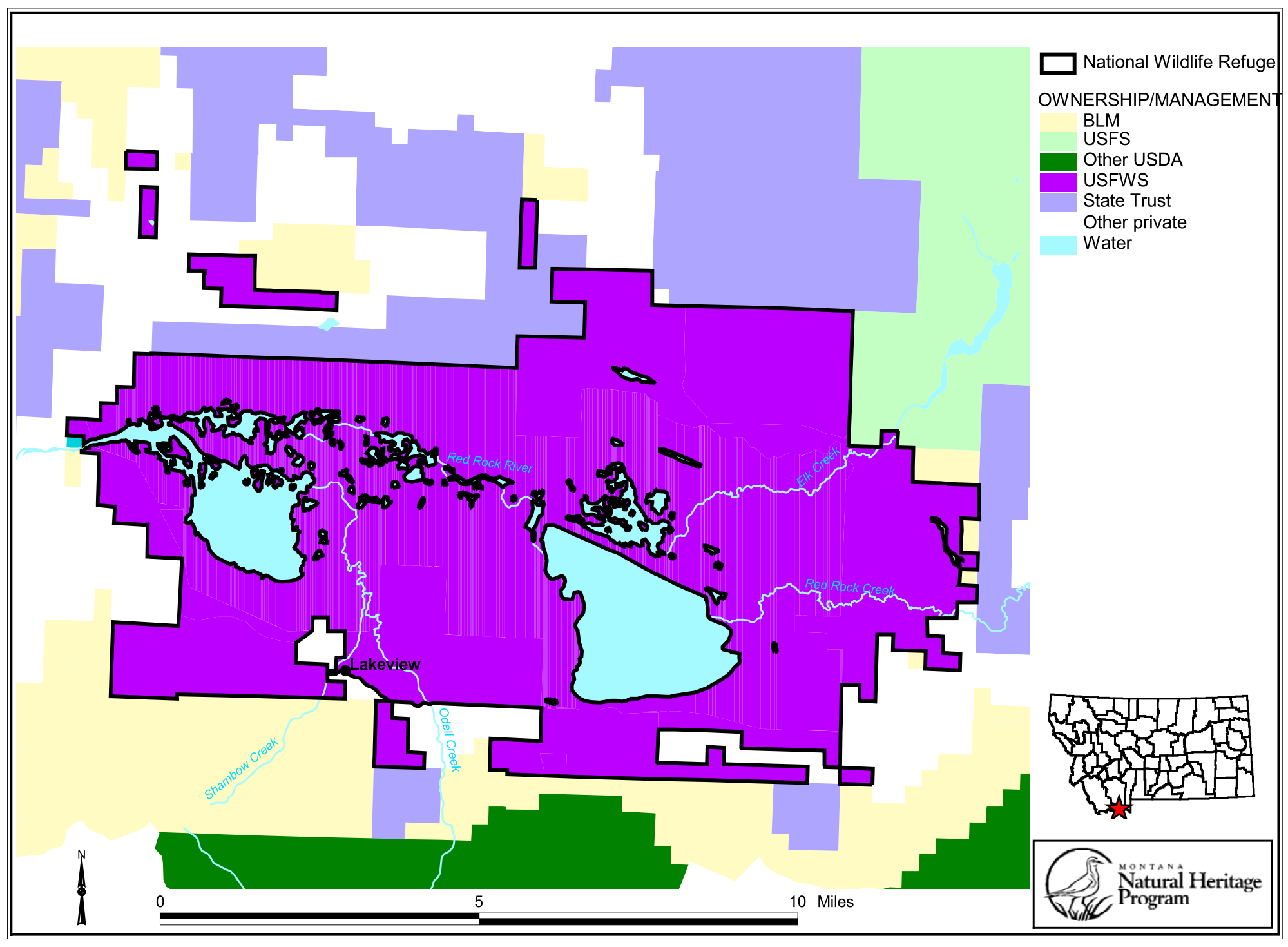


The upland soils of the Refuge have been classified, described and mapped by Nielson and Farnsworth (1965). They found eight of the ten recognized soil orders for the United States and at the finest level of classification, 30 individual soil series representing a high level of variation for such a limited area. Only a few of these many soil types are common and extensive on the Refuge, with $60 \%$ of the mapped area consisting of the Ching, Bug, Raynesford, and Breca series and the Arvada-Beckton, Arvada-Ching, and peatmuck complexes.

\section{Climate}

The climate of greater southwestern Montana can be described as semi-arid and tending toward Continental with a strong winter-summer temperature contrast; however, the numerous mountain ranges generate local distinctions and peculiarities. For instance, the east-west orientation of the Centennial Mountain range positions it to intercept cells of moist air that originate in the Gulf of Mexico and "drift" northward in mid to late summer. These cells are the source of relatively predictable afternoon thundershowers that can be quite intense and can cause the mountain meadows to remain green long into the growing season.

Average annual precipitation at Lakeview $(6,700 \mathrm{ft})$ at the very base of the range is 21.2 inches -- quite high for a valley location (compare to Wisdom, Montana another valley location at 6,100 ft. elevation, which receives only 11.8 inches annually). Precipitation probably exceeds 50 inches near the crest of the Centennial Mountains. Precipitation is relatively evenly distributed throughout the year with the exception of a spring bulge in May and June, a period typically receiving a little less than $1 / 3$ of the average annual precipitation. This precipitation bulge is typical for western Montana's mountainous areas. Not uncommonly, snowfall occurs every month of the year and can accumulate by the end of winter to depths of 150 inches.

The average July maximum temperature is $76^{\circ} \mathrm{F}$; the warmest recorded summer day has never exceeded 94 degrees. The average January minimum is $-1^{\circ} \mathrm{F}$; the coldest day in December, January, and February can be lower than $-40^{\circ} \mathrm{F}$ with an all-time record low of $-49^{\circ} \mathrm{F}$. The yearly mean temperature is only $35^{\circ} \mathrm{F}$, the lowest among recording stations in Montana and lower even than Montana's well-known cold spot, Wisdom (in the Big Hole Valley). Though frost can occur in every month, the frost-free season averages about 51 days, from mid-June to mid-August. These figures alone suggest that the valley is a very cold environment, as could be predicted from its high elevation. This is exacerbated by the narrowness of the valley, the high mountain ranges surrounding it, and hills of the Alaska Basin just to the east, which impede airflow. These factors cause deep ponding of cold air in the Valley and the persistence of snowpack well into spring months. The fact that subalpine forest extends nearly to the valley floor on the north flank of the Centennial Mountains reflects the relatively cold temperature regime of this valley as well as its high precipitation.

\section{VEGETATION}

Though the Refuge constitutes a small area relative to the immensity of the Centennial Valley and Mountains, it contains most of the habitat types found in the region. Beginning in the higher elevation on the north flank of the Mountains, the Refuge includes a variety of seral lodgepole pine (Pinus contorta) stands, and Douglas-fir (Pseudotsuga menziesii) dominated forests on habitat that would potentially support subalpine forest composed of subalpine fir (Abies lasiocarpa) and Engelmann spruce (Picea engelmannii). These types are found in the Sheep Mountain Research Natural Area (RNA) along with limber pine (Pinus flexilis)-dominated old-growth woodlands on Madison limestone and warm exposures. Bunchgrassdominated grasslands occur on areas with thinner soils. 
The extent and biodiversity of wetland and aquatic habitats on the Refuge is significant, and may be greater than that of the entire surrounding region. Wetlands range from tree-dominated Engelmann spruce and quaking aspen to shrub-dominated swamps and carrs (in particular a variety of Salix-dominated types), to emergent herbaceous types such as beaked sedge (Carex utriculata)-dominated marshes and fens. There are even salt-affected, subirrigated areas that support black greasewood (Sarcobatus vermiculatus), Nuttall's alkali grass (Puccinellia nuttalliana) and inland saltgrass (Distichlis spicata)-dominated communities. Some of the most extensive wetlands are those dominated by bulrush (Schoenoplectus $=$ Scirpus) ssp., baltic rush (Juncus balticus), beaked sedge and blue-joint reedgrass (Calamagrostis canadensis). In the past, some of the wetlands (and mesic meadows) were converted to hayfields with exotic pasture grasses, including smooth brome (Bromus inermis), common timothy (Phleum pratense) and Kentucky bluegrass (Poa pratensis).

The Refuge's aquatic environments and submerged macrophyte communities have been characterized by Paullin (1973) using abiotic variables, species composition and successional responses. He found the three most abundant aquatic species to be, in decreasing order, Richardson's pondweed (Potamogeton richardsonii), sago pondweed (Stuckenia pectinatus = Potamogeton pectinatus), and short spike watermilfoil (Myriophyllum sibiricum $=$ Myriophyllum exalbescens), and noted that four species groups could be recognized, associated with water chemistry and substrate characteristics.

By far the most common vegetation type within the greater Centennial region is sagebrush-steppe dominated by mountain big sagebrush (Artemisia tridentata ssp. vaseyana) and the bunchgrass, Idaho Fescue (Festuca idahoensis). Shrub-steppe is characterized by one or more sagebrush taxa that form a modest shrub cover of about $10 \%$ to $25 \%$ canopy cover. The remainder of the shrub-steppe in the region consists of a number of other sagebrush taxa (all of which occur on the Refuge) including basin big sagebrush (Artemisia tridentata ssp. tridentata), low sagebrush (Artemisia arbuscula), early low sagebrush (Artemisia longiloba), and three-tip sagebrush (Artemisia tripartita), each with particular substrate requirements and/or disturbance responses.

The Centennial Sandhills lie on the northern edge of the Refuge and form a unique regional environment supporting a number of sensitive plant species and rare natural communities. The sandhills include several important natural communities. Some are considered long-term stable (or climax) vegetation, such as basin big sage and three-tip sagebrush shrublands with a needle-and-thread grass (Hesperostipa $=$ Stipa comata) or Idaho fescue understory. Other sandhills communities seral, and depend on active sand dunes and blowouts; these include green rabbitbrush (Chrysothamnus viscidiflorus)/needle-and-thread grass and thick-spike wheatgrass / silverleaf phacelia (Elymus lanceolatus / Phacelia hastata) herbaceous vegetation, which is considered globally significant (G2/S2).

\section{METHODS}

As a first step, we reviewed previous inventory and survey work on the Refuge to better utilize existing information and to identify data gaps. Information sources include Refuge files and notes, state and university libraries, and Montana natural Heritage Program (MTNHP) files. An annotated bibliography in Appendix A summarizes much of this previous work. We also reviewed records in the MTNHP databases for completeness, date of last observation and accuracy.

\section{INVENTORY}

We conducted field inventories of plant species, natural communities, terrestrial mollusks, amphibians, birds and small mammals in wetlands and quaking aspen habitats on the Refuge during the summer of 2001. Our objective was to systematically document and evaluate distribution, habitats and status. 
Natural communities were inventoried in the wetland and quaking aspen habitats by walking and recording habitat features. Using a Rapid Ecological Assessment (REA) technique, we recorded the composition, and made ocular estimates of canopy cover and structure of the dominant and subdominant vegetation types. For one or two of the largest quaking aspen trees per plot, we took an increment core sample and measured the diameter at breast height to establish age of the dominant overstory.

Sampling took place across an environmental gradient; this technique provides a description of the total landscape pattern. We collected more detailed ecology plot data in several large patch quaking aspen stands that were relatively homogeneous and had more uniform environmental conditions.

We defined plant associations based on the International Classification of Ecological Communities (NatureServe 2002). This database, developed by The Nature Conservancy (TNC) and NatureServe, forms the basis for a standardized National Vegetation Classification ${ }^{2}$. It incorporates and expands on published state and regional plant community classifications, such as Pfister et al. (1977), Mueggler and Stewart (1980), Hansen et al. (1995), Cooper et al. (1999) and Mueggler (1988). For aquatic communities, we referred to Pierce's classification of aquatic vegetation in western Montana and northern Idaho (Pierce 2000).

Faunal surveys focused on selected aspen and wetlands habitats and a few adjacent sites, and emphasized animal groups that are ecologically important in these habitats or tend to be restricted to them. We made daily visits from July 6 to 9 to six selected quaking aspen stands to document bird use and live-trap small mammals. We also searched briefly for terrestrial snails in a few stands. During this sampling period we were vigilant for amphibians and reptiles, but did not make special effort to survey for them. Several small wetland sites around Upper Red Rock Lake were surveyed for amphibians between 30 August and 1 September, with less attention to quaking aspen stands during this visit.

Small mammals were sampled on six trap lines placed in quaking aspen stands. Trap lines consisted of ten stations each, placed 30 paces apart. Each station consisted of a single Sherman live trap baited with rolled oats and a single museum special snap trap baited with peanut butter. Traps were checked each morning, closed at that time, and reset in the evening. Hard rain prematurely tripped some traps, and elk damaged a few. Total trap-nights sampled was 268 .

We maintained daily lists of birds detected in quaking aspen stands while we tended the small mammal trap lines, and noted evidence of breeding. Snails were sampled by searching through leaf litter and under fallen logs and bark, especially during periods of cooler and wetter weather. We did not examine soil samples for snails, so the list of terrestrial snail species associated with quaking aspen on the Refuge is incomplete. Selected wetland sites were surveyed for the presence of amphibians by slowly traversing through the site and periodically sweeping the water with a net. Counts were made of tadpoles, transformed juveniles, and adults. Particular effort was made to examine small water bodies near the base of avalanche slopes that appeared to be fed by subsurface streams. We were also vigilant for road-killed individuals.

\section{NOMENCLATURE}

\footnotetext{
${ }^{2}$ The International Classification of Ecological Communities is a hierarchical classification that combines floristics and the lowest level (association and alliances) and structure (physiognomy) at the highest levels. Currently the upper levels of the hierarchy have been approved as a classification standard by the Federal Geographic Data Committee (FGDC 1999).
} 
The principle floristic references used for plant identification included Hitchcock et al. (1955-1969) and Dorn (1984). In keeping with International Classification of Ecological Communities (NatureServe 2002), we followed the nomenclature presented in Kartesz (1999) for vascular plants, except for bog birch (Betula glandulosa), where we used the Flora of North America (Furlow 1997). For mosses we followed Anderson (1990) and Anderson et al. (1990).

Two other taxonomic considerations are worth noting. The first concerns one common wetland sedge, often called beaked sedge, which has been erroneously called Carex rostrata in previous studies. While Carex rostrata does occur in northwestern Montana, it is very rare. In this report, we refer to beaked sedge as Carex utriculata (Griffiths 1989). Secondly, we use Engelmann spruce (Picea engelmannii) to include white spruce (Picea engelmannii, Picea glauca), and their hybrids (Daubenmire 1974).

Common and scientific nomenclature of birds cited in this report follows the seventh edition of the.

American Ornithologists' Union Checklist (A.O.U. 1998) and supplements (A.O.U. 2000), mammals follow Foresman (2001), amphibians and reptiles follow Stebbins (1985), fish follow Holton and Johnson (1996), and terrestrial mollusks follow Pilsbry $(1939,1940,1946,1948)$.

\section{Data Management And Analysis}

Community ecology plots were located on the ground using USGS 1:24,000 quad maps, recorded with a Global Position System (GPS) and later uploaded into a Geographic Information System (GIS). All plot data were transcribed into a computerized database for analysis and permanent storage in Heritage data system.

To document the occurrence of quaking aspen and wetland communities ranked as having outstanding quality or considered rare or imperiled, we entered a community occurrence record into the standardized Biological Conservation Database (BCD). The occurrence record includes information such as HGM class, Cowardin class/subclass (Cowardin et al. 1979), dominant species, hydrology, and landscape setting. Community element occurrence records were also geo-referenced, digitized and incorporated into the spatial component of the MTNHP data system.

Information gathered on quaking aspen and wetland habitats was summarized (e.g., general site descriptions, ecological diversity, on- and offsite land uses, management needs) and entered into a site record in BCD. Detailed plant community abstracts were created to characterize both common and uncommon quaking aspen and wetland plant communities. These include information from a variety of sources documenting community range, typical landscape setting, typical species composition, succession, and management. The boundaries of each quaking aspen and wetland site were digitized as polygons and stored associated spatial data files.

We applied Campbell and Barlos's (2001) Key to quaking aspen Risk Factors to prioritize the stands where restoration and conservation activities may be needed to enhance the survival of the quaking aspen stand. The five risk factors for quaking aspen dominated stands are:

1. Conifer cover (understory and overstory) greater than $25 \%$

2. Quaking aspen canopy cover less than $40 \%$

3. Dominant quaking aspen trees greater than 100 years old

4. Quaking aspen regeneration less than 500 stems per acre (5 - 15 feet tall)

5. Sagebrush cover greater than $10 \%$ 


\section{Status of Animal, Plant and Community Inventories}

\section{Animals}

Much of the biological inventory of animals on the Refuge has focused on a few species of high conservation concern. Foremost among these is the Trumpeter Swan. Red Rock Lakes NWR was established specifically to promote the long-term conservation of this bird (Banko 1960), which continues to be a major focus of Refuge activities. Several other bird species of conservation concern that use aquatic and wetland habitats (Table 1) have benefited from the protection of the wetlands and lakes for the swans, however routine monitoring of these species has not been a priority for the Refuge in the past. More recently, bald eagle and peregrine falcon nests have been monitored, the latter species as part of a statewide survey (Sumner and Rogers 1999); pairs of both species routinely hunt waterfowl on the Refuge. Because wetlands are important habitat on the Refuge for a number of animal species, studies of the impacts on the vegetation of native and non-native grazers and browsers have been conducted (e.g., Dorn 1970).

Table 1. Vertebrates of Concern (Carlson 2001) and Montana Partners In Flight priorities I or II documented in the Red Rock Lakes National Wildlife Refuge. Habitat associations within the Refuge are indicated. Brackets around common bird names indicate breeding not documented.

\begin{tabular}{|l|l|l|l|}
\hline Common Name & Scientific Name & Conservation Status & Habitats $^{\mathbf{a}}$ \\
\hline \multicolumn{1}{|c|}{ Fish } & & & \\
\hline Westslope Cutthroat Trout & Onchorhynchus clarki lewisi & Concern & 1 \\
\hline Montana Arctic Grayling & Thymallus arcticus montanus & Concern & 1 \\
\hline Burbot & Lota lota & Review & 1 \\
\hline \multicolumn{1}{|c|}{ Amphibians } & & & \\
\hline Boreal Toad & Bufo boreas & Concern & $1,2,5,6$ \\
\hline \multicolumn{1}{|c|}{ Birds } & & & \\
\hline [Common Loon] & Gavia immer & Concern, PIF I & 1 \\
\hline Horned Grebe & Podiceps auritus & Potential Concern, PIF II & 1,2 \\
\hline Clark's Grebe & Aechmorphorus clarkii & Review & 1,2 \\
\hline [American White Pelican] & Pelecanus erythrorhynchos & Concern & 1 \\
\hline Great Blue Heron & Ardea herodias & Review & 1,2 \\
\hline Black-crowned Night-Heron & Nyctanassa nycticorax & Concern & 2 \\
\hline White-faced Ibis & Plegadis chihi & Concern, PIF II & 2 \\
\hline Trumpeter Swan & Cygnus buccinator & Concern, PIF I & 1,2 \\
\hline Barrow's Goldeneye & Bucephala islandica & PIF II & 1,5 \\
\hline Hooded Merganser & Lophodytes cucullatus & PIF II & 1,5 \\
\hline Bald Eagle & Haliaeetus leucocephalus & Concern, PIF II & 2,5 \\
\hline Northern Goshawk & Accipter gentilis & Concern, PIF II & 5 \\
\hline Swainson's Hawk & Buteo swainsoni & Potential Concern & 3,4 \\
\hline Ferruginous Hawk & Buteo regalis & Concern, PIF II & 3,4 \\
\hline Peregrine Falcon & Falco peregrinus & Concern, PIF II & 2,5 \\
\hline Ruffed Grouse & Bonasa umbellus & PIF II & 5,6 \\
\hline Greater Sage-Grouse & Centrocerus urophasianus & Potential Concern, PIF I & 3 \\
\hline [Black-necked Stilt] & Himantopus mexicanus & Review & 1,2 \\
\hline Long-billed Curlew & Numenius americanus & Potential Concern, PIF II & 3,4 \\
\hline Marbled Godwit & Limosa fedoa & PIF II & $2,3,4$ \\
\hline
\end{tabular}




\begin{tabular}{|c|c|c|c|}
\hline Wilson's Phalarope & Phalaropus tricolor & Review & 1,2 \\
\hline Franklin's Gull & Larus pipixcan & Concern, PIF II & 1,2 \\
\hline Forster's Tern & Sterna forsteri & Concern, PIF II & 1,2 \\
\hline [Black Tern] & Chlidonias niger & Concern, PIF II & 1,2 \\
\hline [Burrowing Owl] & Athene cunicularia & Concern, PIF I & 3,4 \\
\hline Great Gray Owl & Strix nebulosa & Concern & 5 \\
\hline Short-eared Owl & Asio flammeus & Review & 3,4 \\
\hline Calliope Hummingbird & Stellula calliope & PIF II & 5,6 \\
\hline Broad-tailed Hummingbird & Selasphorus platycercus & Concern & 5,6 \\
\hline [Lewis's Woodpecker] & Melanerpes lewis & Concern, PIF II & 5,6 \\
\hline Williamson's Sapsucker & Sphyrapicus thyroideus & Review, PIF II & 5,6 \\
\hline Red-naped Sapsucker & Sphyrapicus nuchalis & PIF II & 5,6 \\
\hline [Three-toed Woodpecker] & Picoides tridactylus & Review, PIF II & 5 \\
\hline Black-backed Woodpecker & Picoides arcticus & Concern, PIF I & 5 \\
\hline Olive-sided Flycatcher & Contopus cooperi & Concern, PIF I & 5,6 \\
\hline Hammond's Flycatcher & Empidonax hammondii & PIF II & 5,6 \\
\hline Cordilleran Flycatcher & Empidonax occidentalis & PIF II & 5,6 \\
\hline Loggerhead Shrike & Lanius ludovicianus & Potential Concern, PIF II & 3,4 \\
\hline [Cassin's Vireo] & Vireo cassinii & Review & 5,6 \\
\hline Brown Creeper & Certhia Americana & PIF I & 5,6 \\
\hline Veery & Catharus fuscescens & PIF II & 6 \\
\hline Sage Thrasher & Oreoscoptes montanus & Review & 3,4 \\
\hline [Tennessee Warbler] & Vermivora peregrina & Review & 5,6 \\
\hline Brewer's Sparrow & Spizella breweri & Potential Concern, PIF II & 3,4 \\
\hline [Lark Bunting] & Calamospiza melanocorys & Potential Concern, PIF II & 3,4 \\
\hline Grasshopper Sparrow & Ammodramus savannarum & Potential Concern, PIF II & 4 \\
\hline Lazuli Bunting & Passerina amoena & PIF II & 6 \\
\hline Bobolink & Dolichonyx oryzivorus & Review & 2,3 \\
\hline Black Rosy Finch & Leucosticte atrata & Concern, PIF II & 3,5 \\
\hline \multicolumn{4}{|l|}{ Mammals } \\
\hline Preble's Shrew & Sorex preblei & Concern & 3,4 \\
\hline Townsend's Big-eared Bat & Corynorhinus townsendii & Concern & 3,5 \\
\hline Black-tailed Jackrabbit & Lepus californicus & Concern & 3,4 \\
\hline Pygmy Rabbit & Brachylagus idahoensis & Concern & 3,4 \\
\hline Great Basin Pocket Mouse & Perognathus parvus & Concern & 4 \\
\hline Gray Wolf & Canis lupus & Concern & 5,6 \\
\hline Grizzly Bear & Ursus arctos horribilis & Concern & 5,6 \\
\hline Fisher & Martes pennanti & Concern & 5 \\
\hline North American Wolverine & Gulo gulo luscus & Concern & 5 \\
\hline Lynx & Lynx canadensis & \begin{tabular}{|l|} 
Concern \\
\end{tabular} & 5 \\
\hline American Bison $^{\mathrm{b}}$ & Bos bison & Concern & $3,4,5,6$ \\
\hline
\end{tabular}

a: 1) aquatic, 2) wetland complex, 3) shrub-steppe, 4) sandhills, 5) coniferous forest, 6) aspen.

b: extirpated 
The Upper Centennial Valley is one of the few places in Montana where fluvial Arctic Grayling persists. Consequently, this fish species has been the focus of several status assessments and monitoring efforts (Nelson 1954, Kaya 1990, Mogan 1996). The Westslope Cutthroat Trout has also generated conservation concern in recent decades (Likens 1984) because of dramatic declines throughout its range, including the Upper Centennial Valley.

The fauna of terrestrial habitats have been less thoroughly surveyed on Red Rock Lakes NWR. A Breeding Bird Survey route runs west from Red Rock Pass through the Refuge and Lakeview; almost half of the 50 point-counts are on the Refuge and provide some basis for long-term monitoring of many forest and shrubsteppe birds. The Refuge checklist is fairly complete for birds, mostly through reports of opportunistic observations rather than systematic surveys. The status, trends and habitat associations of most bird species on the Refuge are not well documented.

Small mammal inventory work has been limited, and mostly in forested habitats on the south side of the Refuge. This has produced a fairly complete mammal checklist for wetland and forest habitats, but little information on status and relative abundance. Intensive trapping in the shrub-steppe and sandhills habitats on the north side of the Refuge (Hendricks and Roedel 2001) recently added four small mammal species to the Refuge checklist, including two of state conservation concern (Hendricks and Roedel 2002). Bats continue to be under-surveyed throughout the Refuge.

The checklist for amphibians and reptiles is probably complete or nearly so (Table 2), thanks to several recent surveys (Roedel and Hendricks 1998, Hendricks and Roedel 2001, Burton et al. 2002). However, habitat associations, need to be more thoroughly documented, especially in upland areas, and status and trends are largely unknown. Figure 2 illustrates the mapped locations of breeding and non breeding amphibians.

Table 2. Amphibians and reptiles documented at Red Rock Lakes National Wildlife Refuge.

\begin{tabular}{|l|l|l|}
\hline Common Name & Scientific Name & Habitats $^{\mathbf{a}}$ \\
\hline \hline Tiger Salamander & Ambystoma tigrinum & $1,2,3,4$ \\
\hline Boreal Toad & Bufo boreas & $1,2,5,6$ \\
\hline Western Chorus Frog & Pseudacris triseriata & $1,2,3,4$ \\
\hline Columbia Spotted Frog & Rana luteiventris & $1,2,5,6$ \\
\hline Western Terrestrial Garter Snake & Thamnophis elegans & $2,3,4,5,6$ \\
\hline
\end{tabular}

a: 1) aquatic, 2) wetland complex, 3) shrub-steppe, 4) sandhills, 5) coniferous forest, 6) aspen

By far, the greatest gap in faunal information is for invertebrates. Only the most preliminary surveys have been conducted, and only for a few selected groups (tiger beetles, butterflies, mollusks). The list of tiger beetles is probably complete for the sandhills (Hendricks and Roedel 2001), but not for other portions of the Refuge; and the documentation of the butterfly fauna is incomplete for all habitats. The list of terrestrial snails known from the Refuge is limited due to lack of focused searches; we conducted a brief survey in quaking aspen habitats during summer 2001. Essentially nothing is known of other invertebrates on the Refuge, except perhaps aquatic insects from analyses of fish diets. 
Figure 2. Mapped records of breeding and non breeding amphibians

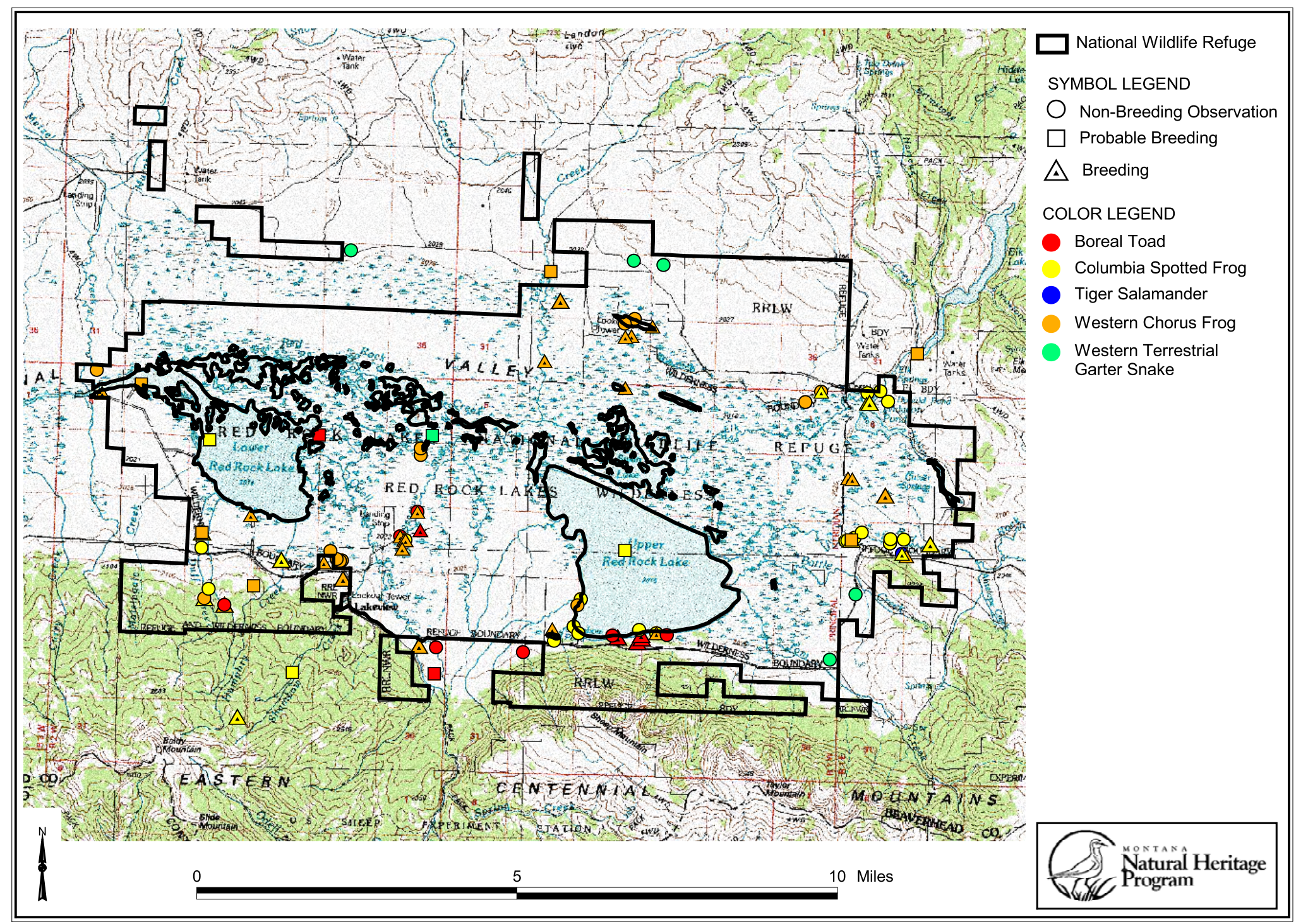




\section{Plants}

Various plant inventories have been conducted in the Centennial region (e.g., Vanderhorst and Lesica, 1994; Lesica, 1990), but few have explicitly targeted the Refuge. While conducting research on interactions of moose, cattle and willows, Dorn (1968) collected extensively and documented 487 species on both the Refuge and northern flanks of the Centennial Mountains; however, references to habitat are general and only the voucher specimens indicate whether a particular species was recorded on the Refuge proper. Lowry (1979), under contract to the Bureau of Land Management, conducted an inventory of the "Centennial Mountains Instant Study Area" finding 362 taxa; his work did not include Refuge lands but points to species that may exist on the Refuge, based on appropriate habitat. Culver (1993), who studied the distribution of sensitive plant species on Bureau of Land Management lands in the area also collected on the Refuge (emphasizing wetlands) and noted the presence of other vascular plant species.

Table 3 lists plant species of concern currently documented from the Refuge in the MTNHP databases (executive boundary). Figure 3 shows mapped observation records for 16 plant species of concern.

Table 3. Vascular Plant Species of Concern (Heidel 2001) documented in the Red Rock Lakes National Wildlife Refuge and immediate surroundings. Habitat associations within the Refuge are indicated.

\begin{tabular}{|l|l|l|l|}
\hline Common Name & Scientific Name & Conservation Status & Habitats $^{\mathbf{a}}$ \\
\hline Sitka columbine & Aquilegia formosa var. formosa & MTNHP Special Status & 5,6 \\
\hline Painted milkvetch & Astragalus ceramicus var apus & BLM Sensitive & 4 \\
\hline Railhead milkvetch & Astragalus terminalis & BLM Sensitive & 3 \\
\hline Idaho sedge & Carex idahoa & BLM \& FS Sensitive & 2 \\
\hline Many-ribbed sedge & Carex multicostata & BLM Watch & 7 \\
\hline Fendler cat's-eye & Cryptantha fendleri & BLM Sensitive & 4 \\
\hline Great Basin Downingia & Downingia laeta & BLM Watch & 2 \\
\hline Sand wildrye & Elymus flavescens & BLM Sensitive & 4 \\
\hline Dwarfgoldenweed & Haplopappus nanus & MTNHP Special Status & 7 \\
\hline Pale evening-primrose & Oenothera pallida var idahoensis & BLM Sensitive & 4 \\
\hline Whipple's beardtongue & Penstemon whippleanus & BLM Sensitive & 7 \\
\hline Platte cinquefoil & Potentilla plattensis & BLM Watch & 3 \\
\hline Fleshy stitchwort & Stellaria crassifolia & BLM Watch & 2 \\
\hline Spiny skeleton weed & Stephanomeria spinosa & BLM Watch & 3 \\
\hline Slender thelypody & $\begin{array}{l}\text { Thelypodium sagittatum ssp. } \\
\text { sagittatum }\end{array}$ & MTNHP Special Status & 2 \\
\hline
\end{tabular}

a: 1) aquatic, 2) wetland complex, 3) shrub-steppe, 4) sandhills, 5) coniferous forest, 6) aspen 7) other

Although noxious weeds are currently at low levels on the Refuge, they represent a potential threat to the native ecosystem. Since 1999, interns working for The Nature Conservancy have inventoried, mapped and removed noxious weeds in the Centennial Valley. Several species have been recorded (Korb, 2002) and treated along the road corridor including spotted knapweed (Centaurea maculosa), common hounds tongue (Cynoglossum officinale), yellow toadflax (Linaria vulgaris), morning glory (Convolvulus arvensis) Canada thistle (Cirsium arvense) and Musk thistle (Carduus nutans), and marsh sowthistle (Sonchus arvensis ssp. uliginosus). 
Figure 3. Mapped observation records of 16 vascular plants of concern

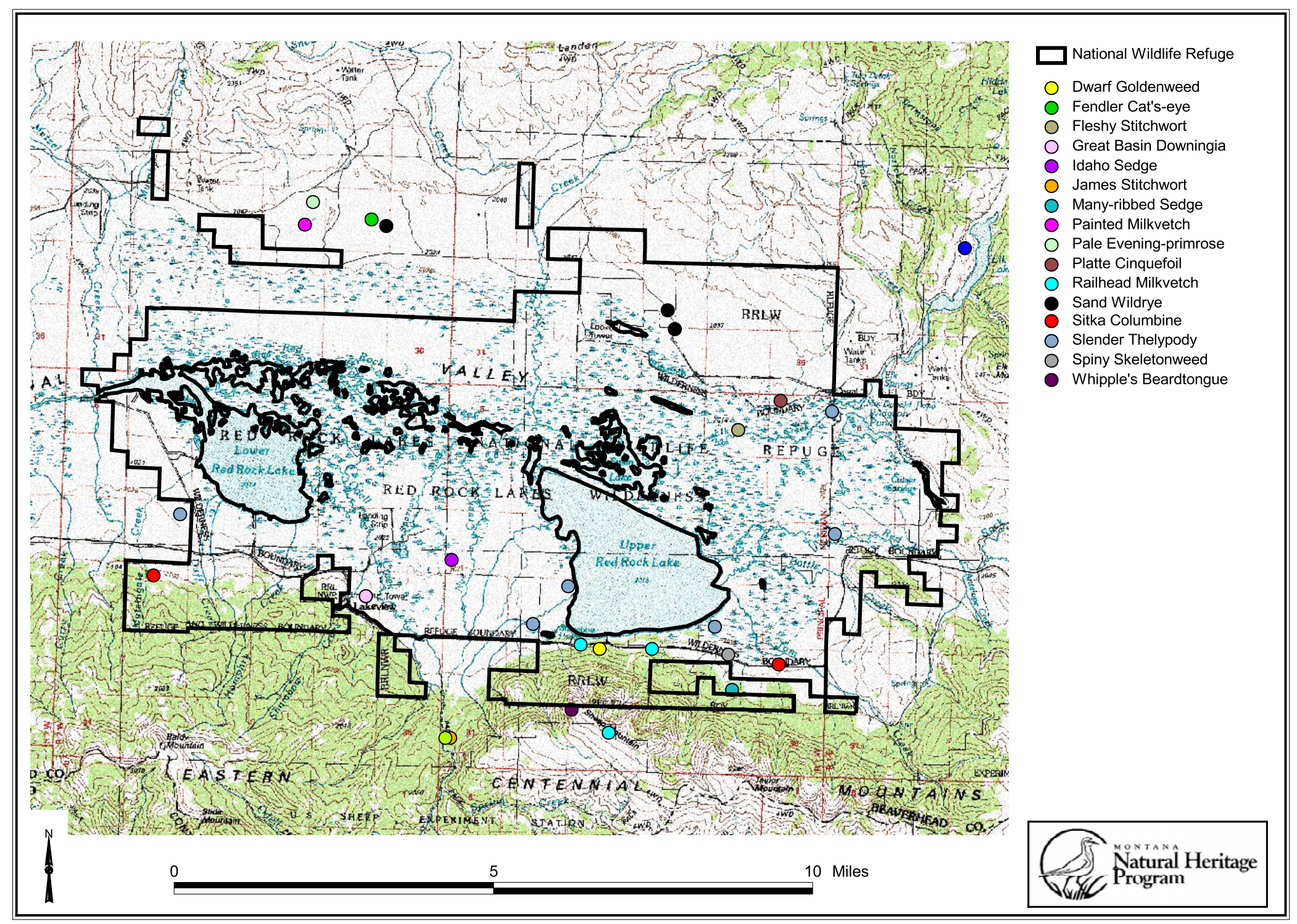


One of the most aggressive weeds, spotted knapweed, often invades natural landscapes and is reported from the road corridor. Ecology plots taken in quaking aspen stands in 2001 indicate high ocular cover of Canada thistle in a couple of locations. Canada thistle seems to be worse in moist riparian settings.

\section{NATURAL COMmunities}

A vegetation map based primarily on potential natural vegetation and drafted explicitly for the Refuge (Cooper 1999) identified 75 plant associations and a number of anthropogenic communities. These communities were then grouped into 5 broad habitat types as illustrated in Figure 4. This map is based on interpretation of large-scale, color-infrared photography along with a few vegetation plots and field notes, and has undergone an accuracy assessment. At the map scale employed $(1: 24,000)$ the great majority of communities appear as complex mosaics; the largest single community types are wetlands characterized by species such as beaked sedge, Baltic rush and bluejoint reedgrass (Calamagrostis canadensis). These wetland types are often associated with concentric zonation of lakes or ponds.

Most plant associations present on the Refuge were described by Cooper et al. (1999) in a report specific for the Beaverhead Mountain Section. The 1999 document incorporates previous studies in the region (DeVelice 1992, Cooper et al. 1995) as well as wetland vegetation types from Hanson et al. (1995), range types from Mueggler and Stewart (1980) and forested associations from Pfister et al. (1977). As far we know, only Cooper et al. (1995), DeVelice (1992), and Hansen et al. (1995) gathered vegetation samples on the Refuge. MTNHP staff collected additional plot data in 2001 for this report.

A preliminary fire history for the north slope of the Centennial Range was compiled by Pohl in 2001. Pohl used fire scar methodology to determine that an extensive, probably stand-replacing fire occurred in 1872; other fires of lesser extent and undetermined severity have occurred approximately every 43 years prior to settlement; only one fire (1930) has occurred since settlement.

Vegetation studies in the Centennial Sandhills have focused on the successional dynamics of the dune blowouts. This landscape supports several rare plants that are associated with early seral environments such as recovering dune blowouts. Blowouts are created through a number of disturbance factors (fire, cattle grazing, pocket gophers and their predators) acting alone or in concert. Lesica and Cooper (1998) presented a descriptive model of the sandhills system for the continued maintenance of early seral habitats.

In an excellent 1973 thesis, Paullin described the aquatic macrophytes and their habitats of the Refuge's water bodies. Among his most intriguing findings was the relatively rapid rate of sedimentation in the Refuge's various water bodies, followed by fairly predictable sere of aquatic communities ultimately leading to emergent vegetation as waters near about $2 \mathrm{ft}$. in depth. In the long term, this process could result in significant loss of aquatic habitat.

Paullin also documented a crash in the cover of Canada waterweed (Elodea canadensis), the preferred food source of the trumpeter swan, , in both the Upper and Lower Red Rock Lakes following the installation of a control structure in 1957 that elevated lake levels approximately one foot. Prior to installation of the control structure, Beed (1956) had noted that Canada waterweed in the Upper Lake grew to pure stands over much of the area, especially in deeper water. Paullin attributed the crash of Canada waterweed to the rise in the Upper Lake level, which increased turbidity, siltation, and water depths. By 1973, white-stalked pondweed (Potamogeton praelongus), fennel-leafed pondweed (Potamogeton pectinatus) and Richardson's pondweed had begun to reinvade the areas formerly dominated by Canada waterweed, however their open 
Figure 4. Aspen, Wetland, Sage-steppe, and Coniferous Forest habitats on the Refuge

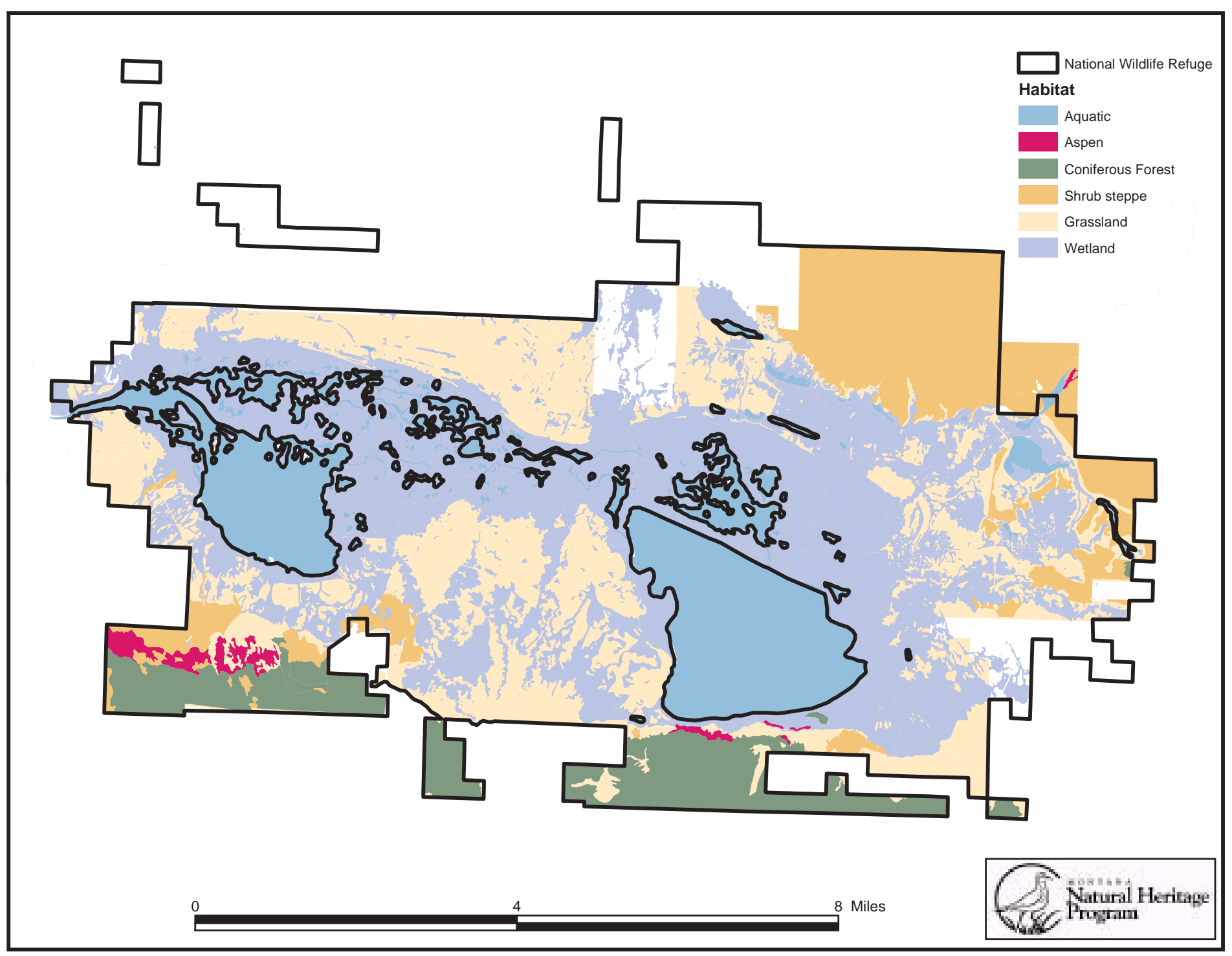


growth pattern contributed little to stabilizing the distrophic conditions on the Upper Lake. Paullin's hypotheses for the decline of Canada waterweed in the Lower Lake and ponds included herbivory by trumpeter swans and a natural sequestration of needed micronutrients in sediments or the tissues of other plants.

\section{OVERVIEW OF WeTLAND AND ASPEN HABITATS}

\section{WeTLAND HaBitats}

\section{Physical SeTting}

Most of the wetlands on the Refuge are marshes associated with Red Rock and Swan Lakes and the Red Rock River. These lakes are remnants of a larger lake that has been reduced through infilling (Sonderegger et al. 1982). They are extremely shallow, with an average depth of $8 \mathrm{ft}$., and support extensive marsh development. Wetlands are also found south of Upper Red Rock Lake on an alluvial fan associated with groundwater discharge.

\section{VEGETATION DESCRIPTION}

\section{LACUSTRINE FRINGE}

Vegetation around Red Rock and Swan Lakes occurs in zones following topographical and soil moisture gradients (soil texture and chemistry may be other important factors in delimiting vegetation communities). Lake bottom sediments, and by extension, lacustrine fringe soils, have high concentrations of available calcium, magnesium, and organic matter and low concentrations of phosphorus and sodium (Paullin 1973). Where sampled, soil texture was silty clay and silty clay loam.

Beaked Sedge occupies the wettest emergent vegetation zone surrounding open water, and forms extensive stands. Water Sedge (Carex aquatilis) and hard-stem bulrush (Schoenoplectus acutus) communities form localized patches within this community. Baltic rush fringes the beaked sedge community and dominates a narrow to broad zone on somewhat higher and drier locations. On wider flats, clustered field sedge (Carex praegracilis) co-dominates with Baltic rush.

On some higher areas associated with greater soil alkalinity, a community of black greasewood-inland saltgrass - Nuttall's alkaligrass inland shrubland predominates. Nuttall's alkaligrass is the dominant grass in this community, although inland saltgrass is abundant in localized patches. The black greasewood shrubland is relatively narrow and grades into a basin wildrye (Leymus cinereus) / Nuttall's alkaligrass herbaceous community, which occupies the least mesic portion of these wetlands.

\section{WiLlow FLATS}

These wetlands occupy an alluvial fan and lakeshore adjacent to Upper Red Rock Lake. They receive groundwater discharge from many small springs and rivulets as well as surface water from Tom and Battle Creeks. There are also many small ponds in the wetland. Soils are comprised of a fibric peat layer from 25 to $>56 \mathrm{~cm}$ deep, although an organic horizon greater than $30 \mathrm{~cm}$ thick appears to be localized. This peat layer is underlain by silty clay loam or silty clay. Some deeper mineral horizons (depth $>50 \mathrm{~cm}$ ) are gleyed, gravelly silty clays with many prominent redoximorphic features.

Most of this site supports a mosaic of low to medium willow communities, including wolf willow (Salix wolfii), / water sedge, wolf willow / baltic rush, and Booth's willow (Salix boothii) / beaked sedge cover ranges from open to dense. The dominant graminoides are water sedge, beaked sedge, and Baltic rush. 
Tufted hairgrass (Deschampsia caespitosa) is locally common in the wolf willow / Baltic rush community. Forbs have low cover in all these stands, the most common species being elephant's-head (Pedicularis groenlandica), wild chives (Allium schoenoprasum), white crane's-bill (Geranium richardsonii), woolly pussytoes (Antennaria lanata), and Canada goldenrod (Solidago canadensis). Plane-leaf willow (Salix planifolia), and alder-leaf buckthorn (Rhamnus alnifolia) are common shrubs. Clumps of tall willows, such as Geyer's willow (Salix geyeriana) and Booth's willow, are locally co-dominant on the lower flat. Although wolf willow is the dominant willow throughout, bog birch (Betula glandulosa) and shrubby cinquefoil (Dasiphora fruticosa ssp.floribunda) co-dominate in many small patches. These areas also have high cover of kinnikinnick (Arctostaphylos uva-ursi) and support a continuous moss layer dominated by golden moss (Tomentypnum niten) and marsh string moss (Aulacomnium palustre).

Tall willow communities, mostly Booth's willow and Geyer's willow with a beaked sedge understory, occur along stream channels and are best developed along Red Rock Creek. Other willows present include Drummond's willow (Salix drummondiana) and Bebb willow (Salix bebbiana). These communities occur on mineral soil, such as loam underlain by fine sandy loam with prominent redoximorphic features.

\section{OLD-GROWTH SPRUCE}

An old-growth Engelmann spruce / field horsetail (Equisetum arvense) community occupies approximately 5.5 hectares near the south shore of Upper Red Rock Lake. The overstory is comprised of mature Engelmann spruce (50-cm diameter-at-breast-height, approximately 170 years old), with scattered very large trees $(>85$ $\mathrm{cm}$ diameter-at-breast-height) present. The ground layer is dominated by field horsetail, with the dwarfshrubs bunchberry (Cornus canadensis) and twinberry (Linnaea borealis) locally abundant. Numerous mesic forbs are present at low cover, including red baneberry (Actaea rubra), western sweet-cicely (Thalictrum occidentale), fragrant bedstraw (Galium triflorum), blunt-fruit sweet-cicely (Osmorhiza depauperata), largeleaf avens (Geum macrophyllum), and arrowleaf groundsel (Senecio triangularis). Graminoids are generally few and include fringed brome (Bromus ciliatus), bluejoint reedgrass, beaked sedge, and soft-leaf sedge (Carex disperma). The soil is a black silt loam with high organic matter content. The spruce and willowdominated communities characterized by a co-occurrence of spruce and willows and a sedge dominated ground layer.

\section{KEY ENVIRONMENTAL FACTORS}

Hydrology is the primary factor influencing these wetlands, with groundwater discharge, stream inflow, precipitation, and infiltration from snowmelt all contributing to the water budget. Upper Red Rock Lake receives thermal groundwater discharge (Sonderegger et al. 1982). Stable groundwater discharge is a key factor affecting the willow flat wetlands. Consistent groundwater discharge and saturated conditions have led to the development of a peat layer at the site and is the primary influence on the structure and composition of site's plant communities. Moose (Alces alces) herbivory may also be influencing vegetation structure through browsing of willows and Engelmann Spruce seedlings and saplings.

\section{Habitat VALUES}

These wetlands support breeding populations of numerous bird and amphibian species of concern, including Trumpeter Swan (S2B, S2N / G4), Black-crowned Night-heron (Nycticorax nycticorax; S3B?,SZN / G5), White-faced Ibis (Plegadis chihi; S1B,SZN / G5), Franklin's Gull (Larus pipixcan; S3B,SZN / G4G5), Forster's Tern (Sterna forsteri; S2B,SZN / G5), and Boreal Toad (Bufo boreas; S3 / G4). Lower Red Rock Lake also supports a population of Montana Arctic Grayling (Thymallus arcticus montanus; S1 / G5T1Q). The spruce stand south of Upper Red Rock Lake contains an active Bald Eagle (Haliaeetus leucocephalus; S3B, S3N / G4, listed threatened) nest site. Boreal Toad toadlets and subadults were found in the strip of 
willows bordering the spruce in three small groundwater discharge ponds in the western portion of the site in late August 2001. It is likely that they use similar breeding habitat throughout the flat. A population of Slender Thelypody (Thelypodium sagittatum ssp. sagittatum, S2 / G4T?) was documented at this site in 1993.

In addition to the species of concern, these wetlands also support breeding populations of Western Chorus Frog (Pseudacris triseriata), Columbia Spotted Frog (Rana luteiventris), and Tiger Salamander (Ambystoma tigrinum).

In general, the willow flats have not accumulated enough organic soil to be technically termed a peatland, although localized patches do have a histic horizon $>30 \mathrm{~cm}$ thick. However, this area is floristically very similar to a calcareous or rich fen, and it shares many of the same functional and habitat values. This type of wetland is relatively rare in Montana in general and is especially rare in southwest Montana. Peatlands provide habitat for 40 species of rare vascular and non-vascular plants, one rare animal, and several rare plant communities, the majority of which are associated with rich fens.

\section{LAND USE}

The hydrology of both Upper and Lower Red Rock Lakes has been altered by a water control structure that has raised lake levels by approximately one foot. This modification may have a significant influence on the ecology of these lakes. Other modifications include levees and the creation of artificial ponds northeast of Swan Lake.

\section{EXOTICS}

Exotic species are a minor component of these wetlands and include localized populations of Meadow Foxtail (Alopecurus pratensis), Reed Canarygrass (Phalaris arundinacea), Kentucky bluegrass, and dandelion (Taraxacum officinale). Exotic species are more abundant in riparian areas (though still a minor component of the vegetation), and include fowl bluegrass (Poa palustris), Kentucky bluegrass, Common timothy (Phleum pratense), Canada thistle, and dandelion

\section{QuAKING ASPEN Habitats}

\section{PhysiCal SeTting}

Quaking aspen is found in a variety of settings on the Refuge, usually occurring as small to large patches within wetlands, sagebrush steppe and Douglas fir forests. The most extensive stands are on lower slopes on the northern flank of the Centennial range, on old mass wasting features (earthflows and landslides). Earthflows formed as soil was saturated by water perched on an impermeable substrate, and became mobilized and flowed downhill. These old flows are readily observed in the southwestern portion of the Refuge, and are elongate to lobate and hummocky in shape. Earthflows consist of granules, pebbles, cobbles, and boulders in an unsorted, unconsolidated to semi-consolidated matrix of clay, silt, and sand (Witkind 1982).

The presence of quaking aspen on these lower slope positions is partially attributed to sub-surface soil moisture from adjacent slopes. In the Intermountain West, quaking aspen appears to be limited primarily by adequacy of the soil moisture required to meet its heavy evapotranspiration demands (Mueggler 1988). Many of the smaller stands of quaking aspen are restricted to a narrow elevation zone near the forest/ steppe transition or adjacent to the riparian areas near Upper Red Rock Lake. 


\section{VEGETATION DESCRIPTION}

At least seven relatively distinct quaking aspen community types occur on the Refuge. These communities separate on a gradient of moisture that is influenced by many interacting factors such as depth to water table, slope position, length of collecting slope, soil texture and depth. Quaking aspen is primarily a seral forest along the northern flank of the Centennial Mountains but may attain long-term dominance in some riparian settings. Conifers are notably scarce in the Quaking aspen / Pinegrass community types. Without disturbance, seral quaking aspen will eventually be replaced by Douglas fir or Subalpine fir. Over time conifers grow above the quaking aspen canopy and eventually over-shadow the quaking aspen. Quaking aspen is shade intolerant and cannot reproduce beneath its own canopy (Brinkman \& Roe 1975; Perala 1990), a factor leading to quaking aspen decline. Quaking aspen also persists as a minor tree beneath conifers, especially where it forms a fringe along the lower slope of coniferous forest.

Quaking aspen stands are generally rich in forbs. Tall forbs include Engelmann's aster (Eucephalus engelmannii $=$ Aster engelmannii), western larkspur (Delphinium occidentale), showy stickseed (Hackelia floribunda), cowparsnip (Heracleum maximum), western sweet-cicely (Osmorhiza occidentalis), Fendler's meadowrue (Thalictrum fendleri), or western meadowrue (Thalictrum occidentale), tall ragwort (Senecio serra), and western valerian (Valeriana occidentalis) in the Centennial region. The more common forbs, easily overlooked amongst the luxuriant graminoids, include silvery lupine (Lupinus argenteus), common yarrow (Achillea millifolium), sticky germanium(Geranium viscosissimum), sweetcicely (Osmorhiza berteroi = Osmorhiza. chilensis), woodland strawberry (Fragaria vesca), and where grazing is heavy dandelion and weedy milkvetch (Astragalus miser).

Two moist quaking aspen community types occur on seeps, springs and wetland ecotones (Upper Lake Campground) near hill toe-slopes with increased soil moisture. The quaking aspen / willow ssp. community characterizes the wettest aspen sites on the Refuge. The aspen canopy is very open, with tall willows including Booth's willow and Drummond willow interspersed in the canopy gaps. Herbs indicating the hydric nature of these sites include field horsetail, beaked sedge, water ragwort (Senecio hydrophilus), water sedge and bluejoint reedgrass; only the first of these attain appreciable cover.

The quaking aspen / bluejoint reedgrass forest community is another moist type found just above the lake margin, where subsurface flow and possibly capillary fringe surrounding the lake likely provide extra soil moisture. This community generally lies immediately adjacent to the quaking aspen/tall forb community or yet wetter herb-dominated wetlands. The tree canopy is very open, with quaking aspen dominant and Engelmann occurring as scattered seedlings and saplings. Blue-joint reedgrass forms a tall sward in some areas. Forbs are scattered and include those in the "tall forb layer" of the following community type, as well as bog orchid (Habenaria ssp), arrowleaf groundsel and twisted-stalk (/Streptopus amplexifolius).

Quaking aspen forms extensive stands on the lower slopes, footslopes and inclined benchlands on the northern flank of the Centennials. These landforms are generally associated with mass wasting features such as old earthflows and landslides. The Quaking Aspen / Pinegrass forest is the most common quaking aspen type associated with this environment, being widespread in the southwest portion of the Refuge. This community has a very simple structure, lacking a distinct shrub layer, but with at least $10 \%$ to as much as $60-80 \%$ cover of pinegrass or Elk sedge (Carex geyeri). From an oblique view, the grass appears to form a continuous carpet. Other important graminoids include blue wildrye (Elymus glaucus), mountain brome (Bromus carinatus) western needlegrass (Achnatherum occidentale = Stipa occidentalis, Kentucky bluegrass, and Wheeler bluegrass (Poa nervosa) -- the last two noted to have high cover. Quaking aspen / Fendler's meadowrue forest is similar in environmental parameters and composition the Quaking Aspen / Pinegrass forest type. Both have a two-layered structure -- a tree stratum of only quaking aspen, and a low- 
herb stratum. Conifers in the reproductive layer are generally infrequent and never abundant. All subalpine fir seedlings from sites visited on the Refuge are browsed.

Quaking aspen / Tall forb forest is found on sites that are generally flat to moisture-collecting (swales, toeslopes), with deep soils derived from colluvium of sedimentary or volcanic origin. This type is also noted for its structural simplicity (Mueggler 1988), lacking a shrub stratum, but with a diverse forb understory. The understory supports small amounts of Engelman spruce and subalpine fir in the sapling and seedling classes. Typical graminoids include mountain brome, blue wildrye, and showy oniongrass (Melica spectabilis); none are common. The Quaking aspen / Canada buffaloberry (Shepherdia canadensis) Forest also has a diverse forb understory.

Quaking aspen / Mountain brome forest is found between the upper lake and the lower alluvial slopes above the lake on the north flank of the Centennial Range. The canopy is dominated by quaking aspen, with suckers in the understory. Quaking aspen suckers and subalpine fir seedlings/saplings are regularly browsed by ungulates. The undergrowth has scattered shrubs, mostly mountain snowberry (Symphoricarpos oreophilus) and Wood's rose (Rosa woodsii), among a dense herbaceous layer variably dominated by mountain brome, blue wildrye, and slender wheatgrass (Elymus trachycaulus = Agropyron trachycaulum or Agropyron caninum), showy oniongrass (Melica spectabilis), Kentucky bluegrass. Very often common yarrow and dandelion are abundant.

The Quaking aspen / Kentucky bluegrass forest is a widespread, grazing-induced community that is common along sloping benches, lower slopes and riparian stringers (often areas where livestock have ease of access). More so than other Refuge types, there may be a subcanopy or sucker shoots of quaking aspen. Kentucky bluegrass, a rhizomatous and grazing-resistant grass, has with high cover values. Other graminoids consistently present are mountain brome, Wheeler's bluegrass (Poa nervosa), and slender wheatgrass (Elymus trachycaulus); dandelion, common yarrow and clover species (Trifolium ssp.) are consistently present and the most abundant forbs.

Short quaking aspen trees are found in Avalanche Chutes and runout areas in a mixed shrubland consisting of chokecherry (Prunus virginiana), mountain maple (Acer glabrum), serviceberry (Amelanchier alnifolia), thimbleberry (Rubus parviflorus) and Canada buffaloberry. The relative abundance of shrubs is likely due to the favorable light regime. The resilience of the quaking aspen and shrubs help ensure their survival on these periodically disturbed sites.

Quaking aspen and sagebrush co-occur in the greater Centennial Valley where sagebrush and aspens stands are adjoining and aspen suckers have encroached on the sagebrush. This phenomenon reflects quaking aspen clonal health, vigor, and reproduction without disturbance. Encroachment into sagebrush has been noted on elk exclosures in Yellowstone National Park, with aspen expanding into and eliminating the sagebrush in a 24-year period.

\section{KEY ENVIRONMENTAL FACTORS}

Quaking aspen habitats on the Refuge are undergoing change. Conifers are replacing quaking aspen through natural successional processes. Disturbance directly influences the structure and composition of quaking aspen stands. Fire is easily the most pervasive factor in maintaining quaking aspen landscapes. Other disturbances including mass wasting, snow avalanches (punctuating the north slope about every half mile), insect attack (especially pine and spruce beetles) and wind-throw have also altered forest structure in the Refuge's vicinity. 
Quaking aspen is a fire-adapted tree having extensive clonal root systems with many shallow spreading horizontal roots that sucker following stand-replacing disturbance. Its adaptive strategy includes a thin bark that provides no protection from heat, so the tree is easily top-killed by fire, and the roots then send up a profusion of sprouts for several years. Fire releases sprout primorida on roots from hormonally controlled growth inhibition root systems (DeByle 1985). Quaking aspen can be highly competitive on burned sites (DeByle et a. 1987). Even where quaking aspen was barely detectable as a component of the pre-fire vegetation, it often dominates a site after fire. Successful regeneration is dependent upon rest from heavy ungulate browsing.

Quaking aspen is especially prone to infection and disease. Animal injury such as bark rubbing and human impacts such as axe wounds inflicted in the campground provide sites for infection. We observed three different pathogens in the quaking aspen forest. White trunk rot (Phellinus tremulae) is a common heart rot fungus. The principle symptom is the hoof shaped conk on the tree trunk. Infection begins in open wounds and eventually causes heart rot. Two canker-type pathogens were also observed. The black canker fungus (Ceratocystis fimbriata) creates a target-shaped wound indicated by black callus folds of dead bark radiating from the center. Quaking aspen canker (Valsa sordida = Cytospora chrysosperma) naturally inhabits quaking aspen bark and is not considered a vigorous parasite (Johnson 1982). This fungus readily enters and parasitizes bark causing bark necrosis, lesions and cankers on the trunk. Heart rot fungus (Phellinus tremulae) occurs in mature and old growth quaking aspen ( $>80$ years), providing valuable habitats to primary cavity nesters such as red-naped sapsucker (Hall and Hart 2001)

\section{HaBitat VALUES}

Although a minor vegetation component on the Refuge, quaking aspen communities are extremely important for wildlife and offer tremendous biodiversity values. We documented 24 bird species in quaking aspen stands during July 2001, including active cavity nests of Red-naped Sapsucker, Hairy Woodpecker, Blackcapped Chickadee, and Tree Swallow in live trees; the sapsucker is a PIF priority II species (Table 2). We observed other species that undoubtedly nest in quaking aspen cavities, including Northern Flicker, Redbreasted Nuthatch, Mountain Chickadee, and House Wren. Bird species richness is often greater in quaking aspen than adjacent conifer forests, and aspen are particularly important for cavity nesting species (Flack 1976, Winternitz 1980). Species richness in quaking aspen is related to greater diversity, larger size, and greater numbers of insects in the understory (Winternitz 1980). Some insectivorous bird species breeding in quaking aspen are also area-dependent, being found in stands greater than some minimum size, but stands as small as 1.2 hectares my be essential for some species in some regions (Johns 1993).

We captured six species of small mammals in quaking aspen stands during our brief early July trapping. The deer mouse (Peromyscus maniculatus) was most abundant (18 of 29 captures, on five of six traplines), followed by six yellow-pine chipmunks (Tamias amoenus) on two traplines, two southern red-backed voles (Clethrionomys gapperi) on two traplines, and one each of meadow vole (Microtis pennsylvanicus), montane vole (Microtis montanus), and western jumping mouse (Zapus princips). Other small mammals observed but not trapped in quaking aspen stands were red squirrel (Tamiasciurus hudsonicus), yellow-bellied marmot (Marmota flaviventris), and northern pocket gopher (Thomomys talpoides). Though we did not survey for bats, several species prefer mature aspen stands over other forest types for cavity roost sites (Crampton and Barclay 1998, Kalcounis and Brigham 1998); we recommend future surveys of bat use in quaking aspen stands on the Refuge.

Species richness of terrestrial snails is often greater in quaking aspen stands than adjacent conifer forest (Beetle 1957, Boag and Wishart 1982, Beetle 1997). Our brief examination of two stands in T14S, R1W, 
sec. 28NENE revealed the presence of seven snail species: Anguispira kochi, Columella edentula, Discus cronkhitei (=whitneyi), Oreohelix subrudis, Vallonia cyclophorella, Vertigo concinnula, and Vitrina alaskana. Discus shimeki, a state Species of Concern (Carlson 2001), is also likely to occur in some of the quaking aspen stands in the Centennial Mountains but was not found during our fieldwork.

Several plant species of concern are associated with quaking aspen habitats. We discovered one new occurrence of Sitka columbine (Aquilegia formosa ssp. formosa, S1/G5) on the Refuge in 2002, adding to three previously-known in the vicinity. This plant species may be found anywhere within the quaking aspen forests that occur on the toe-slope of the Centennial Mountains. Sticky false-starwort (Stellaria jamesiana, $\mathrm{S} 1 / \mathrm{G} 5)$ is another Montana plant species of concern that is associated with quaking aspen habitats in the vicinity of the Refuge.

\section{LAND USE}

Many land use activities take place within quaking aspen habitats on the Refuge. Portions of the quaking aspen habitat are grazed by domestic cattle under an adaptive management prescription. Grazing is frequently cited as the cause of altered graminoid and forb composition, with Kentucky bluegrass, dandelion and clover species all said to increase with grazing. Grazing pressure on quaking aspen suckers is probably also suppressing regeneration, although the impact of domestic livestock relative to wild ungulates is not certain.

Fire suppression, at least in the past, is a significant management practice that has likely changed the vegetation composition, structure, and age class distribution of quaking aspen stands on the Refuge. Fire suppression gives conifers a chance to replace quaking aspen through natural successional processes

Some recreation activities concentrate in quaking aspen stands. The Upper Lake Campground is located in a grove of quaking aspen. This stand is currently under stress from injury and damage to suckers, and a number of quaking aspen pathogens are present (Hagle et al. 1987).

\section{EXOTICS}

Canada thistle and musk thistle, both considered noxious weeds in Montana, are present in quaking aspen on the Refuge. Canada thistle is associated with the moist quaking aspen types. Common timothy and Kentucky bluegrass had a higher cover in grazed quaking aspen stands.

Siberian pea tree (Caragana arborescens), a non-native deciduous tree in the legume family, was found in quaking aspen near the Upper Lake Campground. This tall shrub was planted as a conservation crop in the administrative area and at the upper campground and is now reproducing on its own beneath the canopy of quaking aspen and Douglas fir. Its capability to root sprout and disperse seeds contributes to its ability to successfully reproduce and spread.

The European starling (Sturnus vulgaris) nests in some quaking aspen stands adjacent to spruce forests along the south shore of Upper Red Rock Lake, using cavities excavated by native species. Numbers of starlings could increase, competing with native primary cavity nesters such as woodpeckers and nuthatches, and secondary cavity nesters such as swallows and mountain bluebirds. 


\section{Status of Aspen Habitat}

Our initial investigation of quaking aspen suggests a decline of this habitat in the Centennial region. Quaking aspen habitats provide crucial habitat for a diversity of native species, and their maintenance and restoration is a very important management goal. While natural processes such as insect and disease, fire, and avalanche have a huge influence on aspen stand dynamics, aspen also responds to management activities such as grazing and fire suppression. A major focus of this study was to describe these habitats in detail and

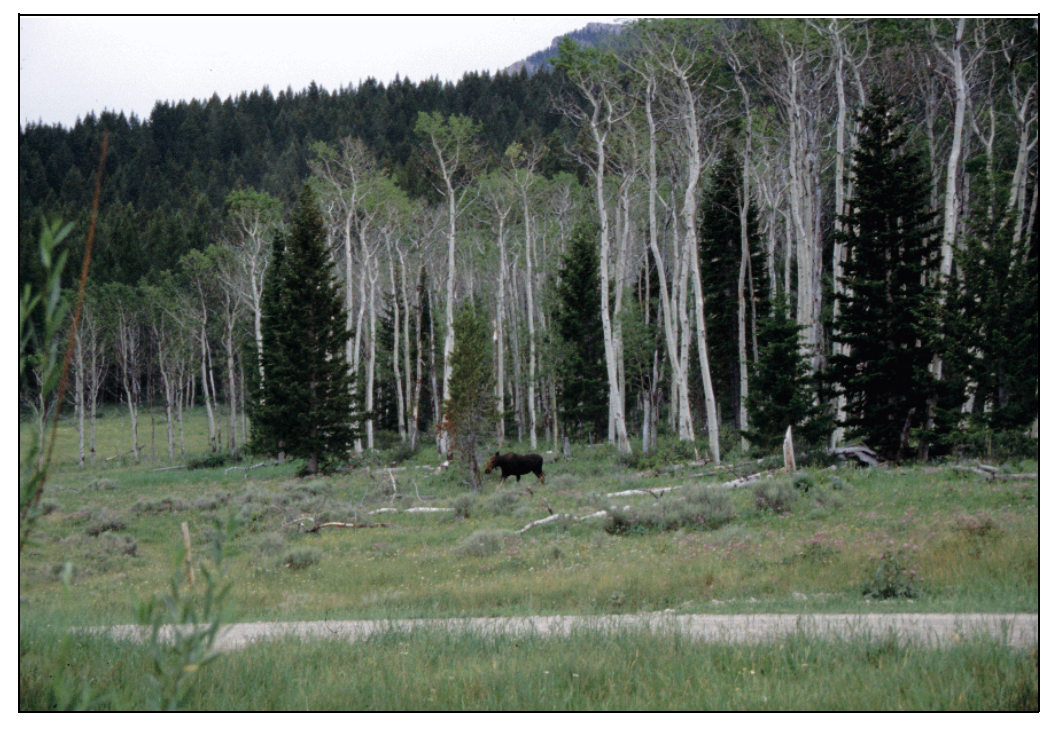
suggest stewardship practices that will help maintain and conserve these ecological systems.

We evaluated quaking aspen ecology plot data and analyzed the risk of local stand extirpation using an assessment developed by Campbell \& Bartos (2001). This assessment is meant to identify and help prioritize stands where restoration and conservation activity may be needed to enhance stand survival. Our sample size was small but did reveal several risk factors that suggest a need for management intervention. One of the leading risks to quaking aspen is succession to conifers along the north flank of the Centennials. Conifer seedlings, saplings and pole size trees are present in the understory in several areas, and a couple stands we sampled had conifer canopy $>40 \%$.

Loss of quaking aspen canopy is a risk factor because low cover $(<40 \%)$ is symptomatic of an unhealthy stand. Several of our samples fell into this risk category. An extreme case of stand deterioration occurred

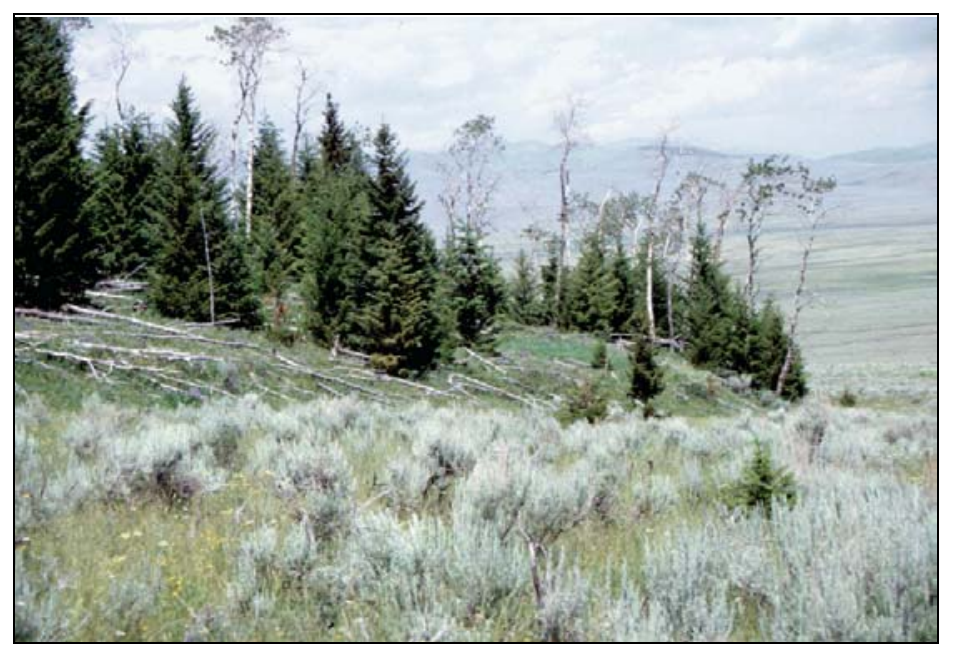
along the edge of earthflow deposits where some conifer, shrubs, grasses, and forbs are replacing lost quaking aspen. There are some exceptions, such as ultra-mesic to wet quaking aspen communities, where $<40 \%$ aspen cover does not necessarily signify a serious decline in vigor.

Old age structure in quaking aspen is another indicator of quaking aspen instability and decline. Age samples collected in 2001 ranged from 64 to 165 , however, the majority were over 100 years old. Quaking aspen in the Northern Rocky Mountains are relatively short-lived, experiencing "natural" mortality between 
100 to 140 years (Cooper and Heidel 1997). Quaking aspen canopies over 100 years old indicate a decline in stand vigor. The aspen overstory in these stands is at or approaching the age of decadence, and could succeed to conifer dominance in a relatively short time. Quaking aspen will naturally develop multi-age stands with saplings and pole size trees replacing the older trees, unless suppressed by ungulate pressure or conifer replacement. This old age structure, the presence of conifers in the understory, and poor regeneration of quaking aspen in the understory places most of these stands at high risk. Riparian settings may be an exception, as those stands appear more stable.

Quaking aspen communities with conifer in the understory are the highest priority for restoration (Campbell and Bartos 2001) on the Refuge (and elsewhere in the Intermountain Region). Conifers are replacing quaking aspen through natural successional processes on the Refuge. In natural fire settings, this successional pathway was periodically interrupted over spatial and temporal scales by stand replacement fires. We speculate that without a renewing disturbance, i.e. fire, the quaking aspen stand structure and composition that qualifies many of these aspen stands as exceptional wildlife habitat will be lost in some measure (Kay 1997). Fire sets the stage for the sprouting of sucker shoots by removing apical dominance of the over-mature trees and killing competing conifers. Even in relatively decadent clones, fire can promote abundant suckering. However, Kay (2001) has made a convincing case that fire accompanied by continued moderate to high intensities of ungulate browsing will eventually eliminate most quaking aspen clones. Gruell and Loope (1974) point out fire once dispersed browsing ungulates enough for quaking aspen to regenerate; this makes a convincing argument for fire planning at large landscapes scales.

Relief from browsing pressure may be critical after any treatment to increase suckering. In many areas we surveyed, quaking aspen suckers were heavily browsed by ungulates, undoubtedly changing the age structure of aspen stands on the Refuge. Heavy browsing of suckers depletes root reserves and threatens survival of clones. Most quaking aspen stands will regenerate without disturbance if ungulate use is low (Kay 2001). The Refuge should monitor aspen regeneration following prescribed or wildlife burns.

Ungulate grazing has also modified the herbaceous understory. Mueggler $(1988,1985)$ suggests that in the Intermountain West, Kentucky bluegrass, weedy milkvetch, common yarrow, dandelion, woods strawberry (Fragaria vesca), and heart-leaf arnica (Arnica cordifolia) will increase with grazing pressure. Although grazing can remove decadent plants and promote regrowth, continuous grazing on quaking aspen suckers can be detrimental. Grazing prescriptions should take extra precaution to reduce the cumulative effects of browsing (wild and domestic) on quaking aspen. This is especially important in smaller, isolated stands where populations of these forbs and introduced grasses like common timothy attain high cover values, such as we observed in the quaking aspen stand north of the road.

The Upper Lake Campground merits special attention. Factors hastening the demise of aspen stands and individuals are its relatively short lifespan coupled with susceptibility to a multitude of debilitating and fatal fungal infections (more than any other tree species in the Northern Rocky Mountains) and insect pathogens, all of which accelerate mortality. Because quaking aspen is prone to insect infestations and disease, deteriorating aspen stands leave potential hazard trees in the campground. A hazard tree inventory should be conducted periodically, using methods outlined by Johnson (1981).

Maintenance of quaking aspen in the long term will require integrated management that considers herbivory, fire, insects and disease. Ideally, quaking aspen should be managed as multi-age stands generally less than 100 years old with adequate regeneration to perpetuate stands. Restoration treatments include rest from 
domestic animals and other ungulate browsing at times, to allow for adequate regeneration and growth beyond sapling size trees.

\section{FUTURE INVENTORY RECOMMENDATIONS}

A habitat-based approach to conservation planning will require a comprehensive understanding of the species and their principle habitats on the Refuge. The primary benefit of gathering information about the biological resources on the refuge is to enable refuge staff to maintain and protect all elements of biological diversityas an integral part of Refuge management and stewardship activities. Prioritizing future inventory should consider if the species of group of species is cited in the enabling legislation or establishing documentation; if the species is federally listed or a candidate for listing; if the species is state listed or of particular regional interest; and if the species or species group is an indicator of ecosystem

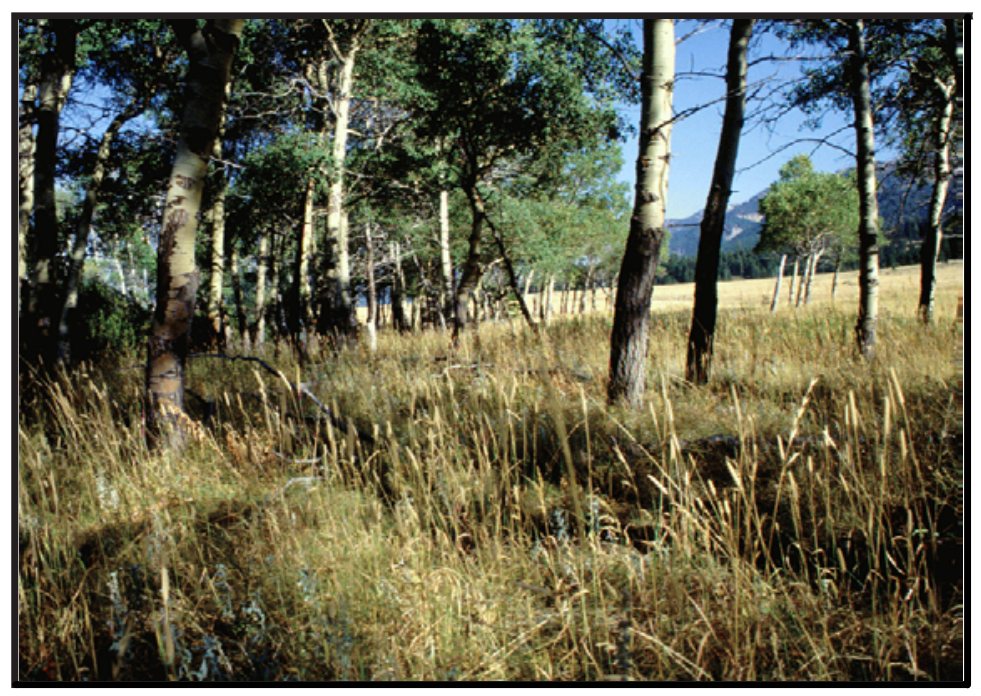
function.

Our examination of inventory records and literature reveal a number of data gaps and suggests a need for continued habitat-specific reviews, similar to this report. We also recommend future inventory for specific plants, animal groups and natural communities. The greatest gap in floristic knowledge concerns the nonvascular species, bryophytes and lichens. We know of no inventory for these species on the Refuge. A good place to start is with a review of state herbaria for moss and lichen records followed by a lichen and bryophyte inventory.

Bats continue to be under-represented through lack of appropriate survey effort throughout the Refuge. Because bats have been found to favor quaking aspen cavities for roosting over cavities in other forest tree types, their use of and dependence on quaking aspen is a priority inventory needed on the Refuge. A thorough analysis of quaking aspen-stand and quaking aspen-cavity dynamics is therefore of value, because bats are dependent upon cavity-excavating species of birds (woodpeckers and nuthatches) to create suitable roost sites.

Future habitat reviews should take place in the aquatic, coniferous, sandhills and sagebrush steppe habitats and some addition focus in wetland and aspen habitats. The Refuge's abundant wetlands and unique habitats such as the Centennial Sandhills have received only cursory inventory for rare plant taxa. The sandhills habitat hosts a number of endemic plants as well as communities that are rare in Montana and treated as species and communities of concern by the Natural Heritage Program. Maintenance of the unique habitat is dependent upon sandhill dune formation and movement, which could be monitored by time sequenced color infra-red aerial photography $(1: 3,000$ to 1,6000$)$.

There is potential for a number of wetland-associated species of concern on the Refuge and a more complete plant inventory is warranted in the wetland habitat. A good example, Alkali Primrose (Primula alcalina) is 
a globally rare plant species (G1) associated with calcareous wetlands in high intermontane valleys similar to the Refuge. This plant species was historically known near Monida and is now presumed extirpated in the state.

Beaver once added to the habitat complexity of drainages along the north slope of the Centennial Mountains and their absence along Duff Creek is perplexing. Further investigation into beaver abundance and distribution on the Refuge and adjacent lands would help determine if restoration efforts are needed.

Aquatic communities on the Refuge have changed significantly since the installation of a water control structure at the outlet of Lower Red Rock Lake in 1957 (Beed 1957, 1958, 1960, Paullin 1973). Paullin (1973) contends that this hydrological modification has altered aquatic communities and is responsible for the significant decline in the cover of Canadian Waterweed, a preferred food for Trumpeter Swans. Paullin also found the potential for significant loss of aquatic habitat due to sedimentation. Paullin's report supports a need for continued study and monitoring of lake sedimentation rates and it's effect on aquatic habitats and the food supply for waterfowl. 


\section{Literature Cited}

American Ornithologists' Union. 1998. Check-list of North American birds, $7^{\text {th }}$ edition. American Ornithologists' Union, Washington, D.C. 829 pp.

American Ornithologists' Union. 2000. Forty-second supplement to the American Ornithologists' Union Check-list of North American birds. Auk 117:847-858.

Anderson, L. E. 1990. A checklist of Sphagnum in North America north of Mexico. The Bryologist 93:500501

Anderson, L. E., H. A. Crum, and W. R. Buck. 1990. List of mosses of North America north of Mexico. The Bryologist 93:448-499.

Banko, W. E. 1960. The Trumpeter Swan. It's history, habits, and population in the United States. North American Fauna Number 63. 214 pp.

Beed, W. E. 1957. Red Rock Lakes aquatic survey. U. S. Fish and Wildlife Service Report. 15 pp. (mimeo).

Beed, W. E. 1958. Memorandum, Red Rock Lakes Refuge. 2 pp. (mimeo).

Beed, W. E. 1960. Range, aquatic plants and water depth check-Red Rock Lakes. U.S. Fish and Wildlife Service Report. 3 pp. (mimeo).

Beetle, D. E. 1957. The mollusca of Teton County, Wyoming. Nautilus 71:12-22.

Beetle, D. E. 1997. Recolonization of burned quaking aspen groves by land snails. Yellowstone Science 5(7):6-8.

Boag, D. A., and W. D. Wishart. 1982. Distribution and abundance of terrestrial gastropods on a winter range of bighorn sheep in southwestern Alberta. Canadian Journal of Zoology 60:2633-2640.

Brinkman, K.A.; and E. I. Roe. 1975. Quaking quaking aspen: silvics and management in the Lake States. Agric. Handb. 486. Washington, DC: U.S. Department of Agriculture, Forest Service. 52 p.

Burton, S. R., D. Patla, and C. R. Peterson. 2002. Amphibians of Red Rock Lakes National Wildlife Refuge: occurrence, distribution, relative abundance, and habitat associations. Herpetological Laboratory, Idaho State University, Pocatello, ID. 66 pp.

Campbell R.B. and D.L. Bartos. 2001. Quaking aspen Ecosystems: Objectives for Sustaining Biodiversity. In: Shepperd, W.D., D. Binkley, D. L. Bartos, T. Stohlgren, and L.G. Lane, compilers. 2001. Sustaining Quaking aspen in Western Landscapes: Symposium Proceedings; 13-15 June 2000; Grand Junction, CO. Proceedings RMRS-P-18. Fort Collins, CO: U.S. Department of Agriculture, Forest Service, Rocky Mountain Research Station. 460 p. 
Carlson, J. 2001. Coordinator, Montana Animal Species of Concern Committee. Montana Animal Species of Concern. Montana Natural Heritage Program and Montana Fish, Wildlife and Parks, Helena, Montana. $12 \mathrm{pp}$.

Cooper, S. V., P. Lesica, R. L. DeVelice, and T. McGarvey. 1995. Classification of southwestern Montana plant communities: Emphasizing those of the Dillon Resource Area, Bureau of Land Management. Montana Natural Heritage Program, Helena, MT. 152 pp.

Cooper, S.V. 1999. Plant associations of the Red Rock Lakes National Wildlife Refuge: Abbreviated community descriptions to accompany vegetation map. Unpublished report to the U. S. Fish and Wildlife Service. Montana Natural Heritage Program, Helena, MT. 39 pp.

Cooper, S. V., C. Jean and B. L. Heidel. 1999. Plant associations and related botanical inventory of the Beaverhead Mountains Section, Montana. Unpublished report to the Bureau of Land Management. Montana Natural Heritage Program, Helena. 235 pp.

Cooper, S. V. and B. L. Heidel. 1997. Population status and ecology of trembling quaking aspen and black cottonwood communities on the Blackfeet Indian Reservation. Montana Natural Heritage Program, Helena, MT. 35 pp. plus appendices.

Cowardin, L. M., V. Carter, F. C. Golet, and E. T. LaRoe. 1979. Classification of wetlands and deepwater habitats of the United States. U.S. Department of Interior, Fish and Wildlife Service, Biological Services Program, FWS/OBS-79/31, Washington D.C.

Crampton, L. H., and R. M. Barclay. 1998. Selection of roosting and foraging habitat by bats in differentaged quaking aspen mixedwood stands. Conservation Biology 12:1347-1358.

Culver, D. R. 1993. Sensitive plant species inventory in the Centennial Valley, Beaverhead County, Montana. Unpublished report for the Butte District, Bureau of Land Management. Montana Natural Heritage Program, Helena. 42 pp. plus appendices.

Daubenmire, R. 1974. Taxonomic and ecological relationships between Picea glauca and Picea engelmannii. Canadian Journal of Botany 52:1545-1560.

DeByle, Norbert V. 1985. The role of fire in quaking aspen ecology. In: Lotan, James E.; Kilgore, Bruce M.; Fisher, William C.; Mutch, Robert W., technical coordinators. Proceedings--Symposium and workshop on wilderness fire; 1983 November 15 - November 18; Missoula, MT. Gen. Tech. Rep. INT-182. Ogden, UT: U.S. Department of Agriculture, Forest Service, Intermountain Forest and Range Experiment Station: 326.

DeByle N.V. 1985. Quaking aspen: Ecology and management in the Western United States.

DeByle, Norbert V.; Bevins, Collin D.; Fischer, William C. 1987. Wildfire occurrence in quaking aspen in the interior western United States. Western Journal of Applied Forestry. 2(3): 73-76.

DeVelice, R. L. 1992. Classification of the plant communities of Beaverhead, Silver Box and Madison Counties, Montana Volume I. Montana Natural Heritage Program, Helena, MT 35 pp. 
Dorn, R. D. 1968. Plants of Red Rock Lakes Refuge and the adjacent Centennial Mountains, Beaverhead County, Montana. Fish and Wildlife Management. Montana State University. Montana/Federal Aid Projects W-98-R, W-73-R. 23 pp.

Dorn, R. D. 1970. Moose and cattle food habits in southwest Montana. Journal of Wildlife Management 34:559-564.

Dorn, R. D. 1984. Vascular Plants of Montana. Mountain West Publishing, Cheyenne, WY. 276 pp.

ECOMAP. 1993. National hierarchical framework of ecological units. Unpublished administrative paper. Washington DC: U.S. Department of Agriculture, Forest Service. 20 p.

Flack, J. A. D. 1976. Bird populations of quaking aspen forests in western North America. Ornithological Monographs No. 19. 97 pp.

Foresman, K. R. 2001. The wild mammals of Montana. American Society of Mammalogists Special Publication No. 12. Lawrence, KS. 278 pp.

Furlow, J. J. 1997. Betualceae. Pages 507-538 in Flora of North America Editorial Committee, editor. Flora of North America north of Mexico, volume 3, Magnoliophyta: Magnoliidae and Hamamelidae. Oxford University Press, New York.

Griffiths, G.C.D. 1989. The true Carex rostrata in Alberta. Alberta Naturalist 19:105-108.

Gruell, G.E.; Loope, L.L. 1974. Relationships among quaking aspen, fire, and ungulate browsing in Jackson Hole, Wyoming. Lakewood, CO: U.S. Department of the Interior, National Park Service, Rocky Mountain Region. 33 p. In cooperation with: U.S. Department of Agriculture, Forest Service, Intermountain Region.

Hall J.H. and D.L. Hart. 2001. Heartrot Fungi's Role in Creating picid nesting Sites in Living Quaking aspen. In: Shepperd, W.D., D. Binkley, D. L. Bartos, T. Stohlgren, and L.G. Lane, compilers. 2001. Sustaining Quaking aspen in Western Landscapes: Symposium Proceedings; 13-15 June 2000; Grand Junction, CO. Proceedings RMRS-P-18. Fort Collins, CO: U.S. Department of Agriculture, Forest Servic4e, Rocky Mountain Research Station. 460 p.

Hagle S.K., S. Tunnock, K.E. Gibson, and C. J. Gibson. 1987. Field Guide to Diseases and Insect pests of Idaho and Montana Forests. USDA Forest Service, State and Private Forestry, Northern Region, Missoula Montana. Publication Number R1-89-54.

Hansen, P.L., R.D. Pfister, K. Boggs, B.J. Cook, J. Joy, and D.K. Hinckley. 1995. Classification and management of Montana's riparian and wetland sites. Miscellaneous Publication No. 54. Missoula, MT: University of Montana, School of Forestry, Montana Forest and Conservation Station. 646 pp.

Hendricks, P., and M. Roedel. 2001. A faunal survey of the Centennial Valley Sandhills, Beaverhead County, Montana. Report to the U.S. Bureau of Land Management and U.S. Fish and Wildlife Service. Montana Natural Heritage Program, Helena, MT. 44 pp. 
Hendricks, P., and M. Roedel. 2002. Preble's shrew and Great Basin pocket mouse from the Centennial Valley Sandhills of Montana. Northwestern Naturalist 83:in press.

Hitchcock, C. L., and A. Cronquist. 1973. Flora of the Pacific Northwest. University of Washington Press, Seattle, WA.

Hitchcock, C. L., A. Cronquist, M. Ownbey, and J. W. Thompson. 1955, 1959, 1961, 1964, 1969. Vascular plants of the Pacific Northwest, 5 vols. University of Washington Press, Seattle.

Holton, G. D., and H. E. Johnson. 1996. A field guide to Montana fishes. Montana Fish, Wildlife \& Parks. Helena, MT. 104 pp.

Johns, B. W. 1993. The influence of grove size on bird species richness in quaking aspen parklands. Wilson Bulletin 105:256-264.

Johnson, D.W. 1981. Tree Hazards: Recognition and Reduction in Recreation Sites. USDA Forest Service Forest Pest Management Technical Report R2-1, Denver CO.

Johnson, D.W., 1982. Forest Pest Management Training Manual. Forest Service Region 1. USDA 11177 W. $8^{\text {th }}$ Ave. Lakewood, CO 80225

Kalcounis, M. C., and R. M. Brigham. 1998. Secondary use of quaking aspen cavities by tree-roosting big brown bats. Journal of Wildlife Management 62:603-611.

Kartesz, J. T. 1999. A synonymized checklist and atlas with biological attributes for the vascular flora of the United States, Canada, and Greenland, $1^{\text {st }}$ edition. In: J. T. Kartesz and C. A. Meacham. Synthesis of the North America Flora, version 1.0. North Carolina Botanical Garden, Chapel Hill, NC.

Kay, C. E. 1997. Is quaking aspen doomed? J. For. 95 (5): 4-11.

Kay, C. E. 2001a. Evaluation of burned quaking aspen communities in Jackson Hole, Wyoming. In: Shepperd, W.D., D. Binkley, D. L. Bartos, T. Stohlgren, and L.G. Lane, compilers. 2001. Sustaining Quaking aspen in Western Landscapes: Symposium Proceedings; 13-15 June 2000; Grand Junction, CO. Proceedings RMRS-P-18. Fort Collins, CO: U.S. Department of Agriculture, Forest Servic4e, Rocky Mountain Research Station. 215-113.

Kay, C. E. 2001b. Long-term quaking aspen exclosures in the Yellowstone Ecosystem. In: Shepperd, W.D., D. Binkley, D. L. Bartos, T. Stohlgren, and L.G. Lane, compilers. 2001. Sustaining Quaking aspen in Western Landscapes: Symposium Proceedings; 13-15 June 2000; Grand Junction, CO. Proceedings RMRS-P-18. Fort Collins, CO: U.S. Department of Agriculture, Forest Servic4e, Rocky Mountain Research Station. 225-240.

Kaya, C. M. 1990. Status report on fluvial Arctic Grayling (Thymallus arcticus) in Montana. Report for Montana Department of Fish, Wildlife and Parks, Helena, MT. 97 pp. 
Korb, N. 2002. Integrated weed management plan for the Red Rock Lakes National Wildlife Refuge. On file at the Refuge.

Lesica, P. and S. V. Cooper. 1998. Succession and disturbance in sandhills vegetation: Constructing models for managing biological diversity. Conservation Biology 13(2): 293-302.

Lesica, P. 1990. Vegetation and sensitive vascular plants of Morrison Lake, Harkness Lakes and Nicholia Creek wetlands, Beaverhead County, Montana. Prepared for the Beaverhead National Forest, Dillon, MT. 28 pp.

Likens, G. A. 1984. The present status and distribution of Westslope Cutthroat Trout (Salmo clarki lewisi) east and west of the Continental Divide in Montana. Report for Montana Department of Fish, Wildlife and Parks, Helena, MT. 163 pp.

Lowry, P. P. II. 1979. Vascular plants of the Centennial Mountains Instant Study Area, Beaverhead County, Montana and adjacent Clark and Fremont Counties, Idaho. Bureau of Land Management. Butte District. 65 pp.

Mogan, J. T. 1996. Status and biology of the spawning population of Red Rock Lakes Arctic Grayling. M.Sc. thesis, Montana State University, Bozeman, MT. 90 pp.

Mueggler, W. F. and W. L. Stewart. 1980. Grassland and shrubland habitat types of western Montana. General Technical Report INT-66. Ogden, UT: U. S. Department of Agriculture, Forest Service, Intermountain Forest and Range Experiment Station. 154 pp.

Mueggler, W. F. 1985. In: DeByle, N.V.; Winokur, R.P., eds. Quaking aspen: ecology and management in the Western United States. Gen. Tech. Rep. RM-119. Fort Collins, CO:U.S. Department of Agriculture, Forest Service, Rocky Mountain Forest and Range Experiment Station: 129 - 134.

Mueggler, W.F. 1988. Quaking aspen community types of the Intermountain Region. General Technical Report INT-250. Ogden, UT: U. S. Department of Agriculture, Forest Service, Intermountain Research Station. $135 \mathrm{pp}$.

Nelson, P. H. 1954. Life history and management of the American Grayling (Thymallus signifer tricolor) in Montana. Journal of Wildlife Management 18:324-342.

NatureServe. 2002. International classification of ecological communities: terrestrial vegetation. Natural Heritage Central Databases. NatureServe, Arlington, VA.

Nielson, E. C. and D. H. Farnsworth. 1965. Soil survey handbook for Red Rock Lakes Migratory Waterfowl Refuge. U. S. Dept. of Agriculture, Soil Conservation Service. 175 pp.

Nesser, J. A., G. L. Ford, C. L. Maynard, and D. S. Page-Dumroese. 1997. Ecological units of the Northern Region: subsections. U.S. Department of Agriculture, Forest Service, Intermountain Research Station, General Technical Report INT-GTR-369. Ogden, UT. 
Paullin, D. G. 1973. The ecology of submerged aquatic macrophytes of Red Rock Lakes National Wildlife Refuge, Montana. Unpublished thesis, University of Montana, Missoula. 171 pp.

Perala, D. A. 1990. Populus tremuloides Michx. quaking aspen. In: Burns, Russell M.; Honkala, Barbara H., technical coordinators. Silvics of North America: Volume 2, Hardwoods. Agriculture Handbook 654. Washington, DC: U.S. Department of Agriculture, Forest Service: 555-569.

Pfister, R. D., B. L. Kovalchik, S. F. Arno, and R. C. Presby. 1977. Forest habitat types of Montana. General Technical Report INT-34. Ogden, UT: U. S. Department of Agriculture, Forest Service, Intermountain Forest and Range Experiment Station. 175 pp.

Pierce, J. 2000. Aquatic Plant Communities of Mountainous Portion of Northern Idaho and Montana. Draft on file at the Montana Natural Heritage Program. 21 pp.

Pilsbry, H. A. 1939. Land Mollusca of North America (north of Mexico), Volume 1, Part 1. Academy of Natural Sciences of Philadelphia, Monograph 3(1):1-574.

Pilsbry, H. A. 1940. Land Mollusca of North America (north of Mexico), Volume 1, Part 2. Academy of Natural Sciences of Philadelphia, Monograph 3(1):575-994.

Pilsbry, H. A. 1946. Land Mollusca of North America (north of Mexico), Volume 2, Part 1. Academy of Natural Sciences of Philadelphia, Monograph 3(2):1-520.

Pilsbry, H. A. 1948. Land Mollusca of North America (north of Mexico), Volume 2, Part 2. Academy of Natural Sciences of Philadelphia, Monograph 3(2):521-1113.

Pohl, K. 2001. A pilot investigation into the fire history of the montane forest of the Centennial Mountains, southwestern Montana: 1743-2000. Submitted to The Nature Conservancy of Montana, Helena. $20 \mathrm{pp}$.

Roedel, M. D., and P. Hendricks. 1998. Amphibian and reptile inventory on the Headwaters and Dillon Resource Areas in conjunction with Red Rock Lakes National Wildlife Refuge: 1996-1998. Montana Natural Heritage Program, Helena, MT. 68 pp.

Romme, W. H.; Turner, M. G.; Wallace, L. L.; Walker, J. S. 1995. Quaking aspen, elk, and fire in northern Yellowstone National Park. Ecology. 76(7): 2097-2106.

Schroeder, R. L. and K. Askerooth. 1999. A habitat-based approach to management of tallgrass prairies at the Tewaukon National Wildlife Refuge/ U.S. Dept. of the Interior, U. S. Geological Survey, Springfield VA: National Technical Information Service.

Sonderegger, J. L., J. D. Schofield, R. B. Berg, and M. L. Mannick. 1982. The Upper Centennial Valley, Beaverhead and Madison Counties, Montana: An investigation of resources utilizing geological, geophysical, hydrochemical and geothermal methods. Memoir 50; Montana Bureau of Mines and Geology, Butte. 53 pp. plus appendices. 
Stebbins, R. C. 1985. A field guide to western reptiles and amphibians, second edition, revised. Houghton Mifflin Co., Boston, MA. 336 pp.

Sumner, J., and R. Rogers. 1999. Montana Peregrine Falcon survey. Report for Montana Department of Fish, Wildlife and Parks, Bozeman, MT. 27 pp. + appendices.

Vanderhorst, J. P. and P. Lesica. 1994. Sensitive plant species survey in the Tendoy Mountains, Beaverhead County, MT. Unpublished report to the Bureau of Land Management. Montana Natural Heritage Program, Helena. 36 pp. plus appendices.

Witkind, I. J. 1982. Geologic map of the Centennial Mountains wilderness study area and contiguous areas, Idaho and Montana. U.S. Geological Survey Map MF 1342-A.

Winternitz, B. L. 1980. Birds in quaking aspen. Pp. 247-257 In Workshop proceedings: management of western forests and grasslands for nongame birds (R. M. DeGraf and N. G. Tilgham, eds.). USDA Forest Service General Technical Report INT-86. Intermountain Forest and Range Experiment Station, Ogden, Utah. 535 pp. 


\section{APPEndiX A. Red Rock LaKes National WiLdLIFe Refuge ANNOTATED BIBLIOGRAPHY}

Banko, W. E. 1960. The Trumpeter Swan. Its history, habits, and population in the United States. North American Fauna Number 63. 214 pp.

Summary of the history, habits and population status of the Trumpeter Swan in the U.S., with emphasis on the Red Rock Lakes population.

Bartlein, P. J., C. Whitlock, and S. L. Shafer. 1997. Future climate in the Yellowstone National Park region and its potential impact on vegetation. Conservation Biology 11:782-792.

Shows projected potential vegetation changes responding to doubling of atmospheric $\mathrm{CO}_{2}$; includes discussion of implications for movement of individual taxa through mountain corridors on the Montana-Idaho border linking the Yellowstone Plateau to the northern Rocky Mountains.

Brown, C. J. D. 1971. Fishes of Montana. Big Sky Books, Montana State University. Bozeman, MT. 207 pp.

Dot distribution maps show fish species collected in Centennial Valley and the refuge, text includes life history accounts

Burton, S. R., D. Patla, and C. R. Peterson. 2002. Amphibians of Red Rock Lakes National Wildlife Refuge: occurrence, distribution, relative abundance, and habitat associations. Herpetological Laboratory, Idaho State University. $66 \mathrm{pp}$.

Summary of June 2001 survey of 81 wetland sites. Four amphibian species were documented on the refuge during the survey: breeding sites were found for western toad, boreal chorus frog, and Columbia spotted frog. Predictive habitat models of occurrence were generated for all amphibian species.

Cooper, S.V. 1999. Plant associations of the Red Rock Lakes National Wildlife Refuge: Abbreviated community descriptions to accompany vegetation map. Unpublished report to the U. S. Fish and Wildlife Service. Montana Natural Heritage Program, Helena, MT. 39 pp.

A 1:24,000 scale existing vegetation map based on limited ground-truth, vegetation plots, and interpretation of large scale CIR aerial photography and documenting in particular the refuge's extensive wetlands. Plant associations, which were used as components of mapping units are briefly described.

Cooper, S. V., C. Jean and B. L. Heidel. 1999. Plant associations and related botanical inventory of the Beaverhead Mountains Section, Montana. Unpublished report to the Bureau of Land Management. Montana Natural Heritage Program, Helena. 235 pp.

An initial attempt to provide a comprehensive treatment of NVCS-recognized plant associations (P.As.) and sensitive plant species for one of Bailey's Section level ecoregions; provides a key to all P. As., a description of most, summarizes the state knowledge regarding the regions sensitive species and profiles landscapes of prime consideration for conservation. 
Cooper, S. V., P. Lesica, R. L. DeVelice, and T. McGarvey. 1995. Classification of southwestern Montana plant communities: Emphasizing those of the Dillon Resource Area, Bureau of Land Management. Montana Natural Heritage Program, Helena, MT. 152 pp.

An initial synthesis of all existing vegetation classifications and plot data (including those from RRLNWR) in the files of MTNHP pertaining to this extensive landscape to produce a key to types and descriptions of most; though study was BLM funded, it applies to lands of all ownership. Sampling was particularly intensive in the Centennial Valley and vicinity.

Clark, T. W., A. H. Harvey, R. D. Dorn, D. L. Genter, and C. Groves, eds. 1989. Rare, sensitive, and threatened species of the Greater Yellowstone Ecosystem. Northern Rockies Conservation Cooperative, Montana Natural Heritage Program, The Nature Conservancy, and Mountain West Environmental Services. $153 \mathrm{pp}$.

Summaries of plant and animal species of conservation concern in the GYE, including specific mention or indication of Arctic Grayling, Ferruginous Hawk and Bald Eagle in the Centennial Valley.

Culver, D. R. 1993. Sensitive plant species inventory in the Centennial Valley, Beaverhead County, Montana. Unpublished report for the Butte District, Bureau of Land Management. Montana Natural Heritage Program, Helena. 42 pp. plus appendices

Survey for state species of concern (MTNHP) focusing on BLM lands (those of FWS received cursory treatment) in the Centennial Region conducted in 1993. Report includes results of survey, species information and recommendations for revising the BLM sensitive plant species list. All sensitive species locations digitized and in GIS at MTNHP.

Culver, D. R. 1994. Floristic Analysis of the Centennial Region, Montana. Masters thesis, Montana State University, Bozeman. 199 pp.

An original floristic inventory combined with preexisting lists by various researchers used to show Centennial Region flora highly related to Rocky Mountain flora and that the species richness of this region does not differ from that of other region of similar topography in western North America; contains useful appendix of species distribution by four vegetation zones.

Devan, G. A. 1964. Mammal checklist (letter and typescript).

Lists 44 mammal species for the refuge.

Dorn, R. D. 1968. Plants of Red Rock Lakes Refuge and the adjacent Centennial Mountains, Beaverhead County, Montana. Fish and Wildlife Management. Montana State University. Montana/Federal Aid Projects W-98-R, W-73-R. 23 pp.

This floristic list is a by-product of Dorn's thesis work and sampling emphasized the RRLNWR; presents a useful matrix of species occurrence by ten distinct environments. 
Dorn, R. D. 1970. Moose and cattle food habits in southwest Montana. Journal of Wildlife Management 34:559-564.

Analysis of diets on the refuge shows minor overlap; 15 species of willow noted, all potentially important for moose.

Douglas, D. C., J. T. Ratti, R. A. Black, and J. R. Alldredge. 1992. Avian habitat associations in riparian zones of Idaho's Centennial Mountains. Wilson Bulletin 104:485-500.

Study was conducted in eastern portion of Centennial Mountains in Idaho opposite the refuge. Many bird species showed discrete patterns of habitat preferences along a moisture gradient within riparian habitat; the data indicate that subtle changes to riparian areas from grazing, timber harvest, drainage diversion, etc. may have severe impacts on the bird community.

Gomez, D. 1994-2001. Trumpeter Swan survey of the Rocky Mountain population/ U.S. flocks, Fall. U.S. Fish and Wildlife Service, Red Rock Lakes National Wildlife Refuge.

Annual status summary of September surveys, including the Centennial Valley birds; status/count of summer Rocky Mountain population.

Gomez, D. 1995-2000. Mid-winter survey: Rocky Mountain population of Trumpeter Swans. U.S. Fish and Wildlife Service, Red Rock Lakes National Wildlife Refuge.

Annual results of January-February surveys, including the Centennial Valley birds; intended to provide a total count of the Rocky Mountain population.

Gould, W. R., and C. J. D. Brown. 1970. Distribution of sculpins (Cottidae) in Montana. Copeia 1970:594595.

Map shows specimen records for Cottus bairdi in the Centennial Valley.

Greater Yellowstone Coalition. 1986. A model for information integration and management for the Centennial Ecosystem. Unpublished report. 184 pp.

Includes faunal observation summaries for several species of conservation concern, including Grizzly Bear encounters in the Centennial Mountains between 1970-1981.

Green, D. M., T. F. Sharbel, J. Kearsley, and H. Kaiser. 1996. Postglacial range fluctuation, genetic subdivision and speciation in the western North American Spotted Frog complex, Rana pretiosa. Evolution 50:374-390.

Includes specimens from the refuge and description of their allozyme diversity. 
Harmata, A. R., G. J. Montopoli, B. Oakleaf, P. J. Harmata, and M. Restani. 1999. Movements and survival of Bald Eagles banded in the Greater Yellowstone Ecosystem. Journal of Wildlife Management 63:781-793.

Shows movements of eagles out of the GYE to the west and south; neither the refuge nor Centennial Valley are specifically mentioned, but movements from and through area are indicated.

Hendricks, P., and M. Roedel. 2001. A faunal survey of the Centennial Valley Sandhills, Beaverhead County, Montana. Report to the U.S. Bureau of Land Management and U.S. Fish and Wildlife Service. Montana Natural Heritage Program. 44 pp.

Survey of vertebrates and selected invertebrates (tiger beetles, some butterflies) occupying the sandhills; added six mammal species to refuge list.

Hendricks, P. and M. Roedel. 2002. Preble's Shrew and Great Basin Pocket Mouse from the Centennial Valley Sandhills of Montana. Northwestern Naturalist 83:in press.

Summary of records and habitat association information for these two small mammals of conservation concern in the sandhills.

Hoffmann, R. S., D. L. Pattie, and J. F. Bell. 1969. The distribution of some mammals in Montana. II. Bats. Journal of Mammalogy 50:737-741.

Includes a published record for Townsend's Big-eared Bat from the refuge; specimens deposited at the University of Montana.

Hoffmann, R. S., P. L. Wright, and F. E. Newby. 1969. The distribution of some mammals in Montana. I. Mammals other than bats. Journal of Mammalogy 50:579-604.

Includes first published specimen and sight records of Pygmy Rabbit and Black-tailed Jackrabbit, respectively, from the Centennial Valley.

Kaya, C. M. 1990. Status report on fluvial Arctic Grayling (Thymallus arcticus) in Montana. Report for Montana Department of Fish, Wildlife and Parks, Helena. 97 pp.

Includes the status of the Red Rock River population.

Korb, N. 2001. Red Rock Watershed Weed Project Summary. On file at The Nature Conservancy Field Office, Helena, MT.

Includes a summary of inventory and suppression activities in the Centennial Valley. Identifies several noxious weeds present on the refuge. 
Lesica, P. and S. V. Cooper. 1997. Presettlement vegetation of southern Beaverhead County, Montana. Unpublished report to the Bureau of Land Management. Montana Natural Heritage Program, Helena, MT. $35 \mathrm{pp}$.

Authors attempted to use historical records (journals, etc.) as well as repeat sampling to test several hypotheses regarding pre-settlement vegetation patterns with the primary finding being that it was difficult to make any definitive statements regarding change. Almost certainly there is less big sagebrush in the valley locations with the upslope populations showing localized variation; willow populations have also demonstrably decreased.

Likens, G. A. 1984. The present status and distribution of Westslope Cutthroat Trout (Salmo clarki lewisi) east and west of the Continental Divide in Montana. Report for Montana Department of Fish, Wildlife and Parks, Helena. 163 pp.

Includes the status of this species in the Red Rock River system.

Mattson, D. J., K. C. Kendall, and D. P. Reinhart. 2001. Whitebark pine, grizzly bears, and red squirrels. Pp. 121-136 In Whitebark Pine communities, ecology and restoration (D. F. Tomback, S. F. Arno, and R. E. Keane, eds.). Island Press, Washington, D.C. 440 pp.

Chapter includes map showing whitebark pine seeds occur in $>10 \%$ of bear scats in the Centennial and Gravelly Mtns. Other chapters include material on disease and threats pertinent to Centennial area.

McEneaney, T. 1984. The Centennial Valley of Montana - an assessment of wildlife and wildlife habitat values. Red Rock lakes National Wildlife Refuge. 16 pp.

Brief summary of habitats and plant species of special interest, and associated wildlife of special interest in the valley.

McEneaney, T. 1984. 1984 Tri-state Trumpeter Swan survey. U.S. Fish and Wildlife Service, Red Rock Lakes National Wildlife Refuge. 15 pp.

Summary of Fall surveys, including the Centennial Valley birds.

McEneaney, T. 1985. 1985 mid-winter Trumpeter Swan survey. U.S. Fish and Wildlife Service, Red Rock Lakes National Wildlife Refuge. 7 pp.

Summary of winter surveys, including the Centennial Valley birds.

McEneaney, T. 1993. The birder's guide to Montana. Falcon Press. Helena, MT. 316 pp.

Includes an account of the Centennial Valley and Red Rock Lakes NWR, with locations mentioned for a variety of bird species. 
Meagher, M. M. 1973. The Bison of Yellowstone National Park. National Park Service Scientific Monograph Series Number One. 161 pp.

Includes brief mention of wild bison present in the Red Rock Lakes area, probably in the early decades of the $20^{\text {th }}$ Century or earlier.

Mitchell, C. D. 1994. Trumpeter Swan (Cygnus buccinator). In The Birds of North America, No. 105 (A. Poole and F. Gill, Eds.). Philadelphia: The Academy of Natural Sciences; Washington, D. C.: The American Ornithologists' Union. 24 pp.

Recent summary of the life history and ecology of Trumpeter Swans, with scattered reference to Red Rock Lakes NWR.

Mogan, J. T. 1996. Status and biology of the spawning population of Red Rock Lakes Arctic Grayling. M.Sc. thesis, Montana State University, Bozeman. 90 pp.

Still spawning in Red Rock Creek and Odell Creek, but not in ten other historical spawning tributaries.

Nelson, P. H. 1953. Life history and management of the American Grayling (Thymallus signifer tricolor) in Montana. M.Sc. thesis, Montana State College, Bozeman. 45 pp. sampled.

Study focused on the Centennial Valley and Red Rock Lakes area; includes list of other fish species

Nelson, P. H. 1954. Life history and management of the American Grayling (Thymallus signifer tricolor) in Montana. Journal of Wildlife Management 18:324-342. sampled.

Conducted in the Upper Centennial Valley and on the refuge; includes list of other fish species

Niethammer, K. 1993. 1993 Trumpeter Swan survey of the Rocky Mountain population/ U.S. flocks, Fall. U.S. Fish and Wildlife Service, Red Rock Lakes National Wildlife Refuge. population.

Summary of Septembersurvey results, including the Centennial Valley birds; count of the summer

Niethammer, K. 1994. 1994 mid-winter survey: Rocky Mountain population of Trumpeter Swans. U.S. Fish and Wildlife Service, Red Rock Lakes National Wildlife Refuge. 19 pp.

Summary of January-February survey results, including the Centennial Valley birds; total count of the Rocky Mountain population. 
Page, R. D. 1976. The ecology of the Trumpeter Swan on Red Rock Lakes National Wildlife Refuge. Ph. D. Dissertation, University of Montana, Missoula.

Ecological study conducted at the refuge.

Paullin, D. 1971. The ecology of submerged aquatic macrophytes of Red Rock Lakes NWR, Montana. Masters thesis. University of Montana, Missoula. $171 \mathrm{pp}$.

Author sampled almost all RRLNWR water bodies for submerged macrophytes finding much overlap in species distribution and difficulty in defining vegetation types; his discussion of succession is very pertinent, noting a crash in Elodea canadensis (primary Trumpter Swan food source) since construction of a control structure and the concomitant increase in water tubidity.

Pohl, K. 2001. A pilot investigation into the fire history of the montane forest of the Centennial Mountains, southwestern Montana: 1743-2000. Submitted to The Nature Conservancy of Montana, Helena. 20 pp.

Restricted to a narrow east-west transect on the north slope of Centennial Range, this study offirescarred trees shows that prior to settlement the fire-return interval was on the order of 40 to 50 years and that following settlement the fire-return interval has increased to somewhat greater than 60 years.

Povilitis, T., and M. H. Mahr. 1998. Montana's Centennial Valley: natural diversity hot spot and wildland corridor. Natural Areas Journal 18:116-123.

Overview of the valley system, including discussion of animal species of conservation concern.

Rauscher, R. L. 1997. Status and distribution of the Pygmy Rabbit in Montana, final report. Montana Department of Fish, Wildlife and Parks. 19 pp. + appendices.

Summary of records and survey results in Montana, including the Centennial Valley and refuge.

Restani, M. 1991. Resource partitioning among three Buteo species in the Centennial Valley, Montana. Condor 93:1007-1010. hawks.

Nest site characteristics and food habits of coexisting Red-tailed, Swainson's, and Ferruginous

Roedel, M. D., and P. Hendricks. 1998. Amphibian and reptile inventory on the Headwaters and Dillon Resource Areas in conjunction with Red Rock Lakes National Wildlife Refuge: 1996-1998. Montana Natural Heritage Program. Helena. 68 pp.

Survey results and compilation of amphibian and reptile records for the refuge and Centennial Valley. 
Sonderegger, J. L., J. D. Schofield, R. B. Berg, and M. L. Mannick. 1982. The upper Centennial Valley, Beaverhead and Madison Counties, Montana. Montana Bureau of Mines and Geology Memoir 50. 97 pp.

Discusses the structural and surficial geology; map of the upper $N$ side of the valley has the sandhills mapped.

Sumner, J., and R. Rogers. 1999. Montana Peregrine Falcon survey. Report for Montana Fish, Wildlife and Parks, Bozeman. 27 pp. + appendices.

Includes historical and active eyrie records for site history and productivity of Peregrine Falcons; covers sites in the Centennial Valley, including Red Rock Lakes National Wildlife Refuge.

Swenson, J. E., K. L. Alt, and R. L. Eng. 1986. Ecology of Bald Eagles in the Greater Yellowstone Ecosystem. Wildlife Monograph No. 95. 46 pp.

Discusses nesting habitat, population numbers, trends and breeding biology of the "Continental Unit” Bald Eagle subpopulation, which includes Red Rock Lakes National Wildlife Refuge.

Thompson, L. S. 1982. A 1979 census of Great Blue Heron colonies in Montana. Proceedings of the Montana Academy of Sciences 41:23-27.

One colony noted in latilong, probably in the Centennial Valley. More recent record in letter of 19 June 1989 from C. D. Mitchell (asst. refuge manager) to D. Genter mentions a colony[size?] on the N shore of Upper Red Rock Lake.

United States Fish and Wildlife Service, Red Rock Lakes National Wildlife Refuge. No date. Mammals of the Red Rock Lakes National Wildlife Refuge.

Checklist (post-1978 and pre-1999) indicating status and habitat of 49 mammal species, including Least Chipmunk, Wolverine, Gray Wolf, Raccoon, and White-tailed Deer not in Devan (1964).

United States Fish and Wildlife Service, Red Rock Lakes National Wildlife Refuge. 2000. Birds of the Red Rock Lakes National Wildlife Refuge and the Centennial Valley, Montana.

Checklist indicating seasonal occurrence and breeding status of 232 bird species.

United States Fish and Wildlife Service, Red Rock Lakes National Wildlife Refuge. 2000. Fish of the Centennial Valley.

Checklist indicating status and distribution of 12 fish species. 